\title{
Li/Ca enrichments in great scallop shells (Pecten maximus) and their relationship with phytoplankton blooms
}

\author{
Julien Thébault ${ }^{\mathrm{a}, *}$, Laurent Chauvaud ${ }^{\mathrm{a}}$ \\ ${ }^{a}$ Université de Brest, Institut Universitaire Européen de la Mer, Laboratoire des sciences de l'environnement marin (UMR6539 CNRS/IRD/UBO), rue \\ Dumont d'Urville, 29280 Plouzané, France
}

\begin{abstract}
Phytoplankton dynamics in coastal oceans is a major component of the global biogeochemical carbon cycle, and is currently affected by global change through modifications in levels of primary productivity and composition of phytoplankton communities. Despite many attempts, no straightforward geochemical proxy has been found yet in marine biogenic carbonates for reconstruction of past phytoplankton dynamics with high temporal resolution. Here, we report on subweekly variations of lithium-to-calcium ratios $\left(\mathrm{Li} / \mathrm{Ca}_{\text {shell }}\right)$ along the axis of maximum growth of great scallop shells (Pecten maximus) collected alive between 1999 and 2007 in the bay of Brest, northwest France. Inter-individual variability of $\mathrm{Li} / \mathrm{Ca}_{\text {shell }}$ time series was very low, suggesting an environmental control on the incorporation of Li within shells. Conversely, inter-annual variability of $\mathrm{Li} / \mathrm{Ca}_{\text {shell }}$ was high, with limited seasonal $\mathrm{Li} / \mathrm{Ca}_{\text {shell }}$ variations in 2001 and 2007, and the presence of Li enrichments from May to July in 1999 and 2004. Comparison of these results with shell growth measurements (increment width) and environmental parameters suggests (i) that shell calcification rate is likely the main factor controlling incorporation of $\mathrm{Li}$ in Pecten maximus shell calcite, (ii) that seawater temperature has only a weak positive influence on $\mathrm{Li} / \mathrm{Ca}_{\text {shell }}$ of this species over the range $8-18^{\circ} \mathrm{C}$, and (iii) that during diatom blooms, additional amounts of Li may be trapped in the shell following dissolution of Li-rich frustules of edible species in the digestive tract of scallops, being responsible for $\mathrm{Li} / \mathrm{Ca}_{\text {shell }}$ peaks. Therefore, we suggest that $\mathrm{Li} / \mathrm{Ca}$ shell ratio may be a novel proxy for timing and magnitude of diatom blooms in coastal ecosystems. Analysis of ancient shells may thus provide useful information on past phytoplankton dynamics and on the importance of recent shifts observed from diatoms to non-siliceous phytoplankton in coastal areas affected by anthropogenic activities.
\end{abstract}

Keywords: bivalve, calcite, lithium, shell growth, phytoplankton, diatom

\section{Introduction}

In the past decades, a consensus emerged in the international scientific community: human activities have, or will shortly have, consequences on the structure and functioning of all the Earth's ecosystems, especially on coastal areas of the world ocean (Jackson, 2001). Coastal zones are one of the most dynamic interfaces of the biosphere, both from a geochemical and a biological point of view (Twilley et al., 1992); therefore, they hold an important place along the land-sea continuum. The most significant anthropogenic impacts affecting coastal ecosystems are related to changes in inputs of sediments, organic and inorganic pollutants, and above all, nutrients (nitrogen, phosphorus). The latter can induce changes of trophic conditions (up to eutrophication) and disturbances in phytoplankton dynamics (changes in primary production levels, in bloom frequency, in the composition of microalgal communities such as shifts from diatoms to dinoflagellates; Cloern, 2001). Phytoplankton are the keystone organism of the oceans. Indeed, although they account for only $0.1 \%$ of the total photosynthetic biomass on Earth, phytoplankton are responsible for nearly half of the biospheric net primary production, annually fixing ca. $50 \mathrm{PgC}$ by photosynthesis (Field et al., 1998). About 14\% of this global ocean production, along with $80-90 \%$ of new production, takes place in coastal oceans that yet occupy less than $0.5 \%$ of the ocean volume (Chen et al., 2003). As a consequence, phytoplankton dynamics in the coastal zone is undoubtedly a major component of the global geochemical carbon cycle. Beyond this impact, these tiny ocean primary producers also serve as the base of the ocean food chain, supplying food for higher trophic levels; therefore their abundance determines the overall health of ocean ecosystems and fisheries.

In order to assess the respective roles of natural variability and anthropogenic activities in the current changes in structure and functioning of coastal ecosystems, it is crucial to quantify past phytoplankton dynamics, especially on levels of primary productivity and composition of phytoplankton communities which both seem to be affected by global change (Sarmiento et al., 2004; Miller et al., 2006). A problem is that conventional monitoring time series (electronic instruments, periodic water sampling) are relatively sparse, scattered, often very short (especially for phytoplankton) and therefore, do not encompass low frequency cycles of natural variations of coastal environments (Jack- 


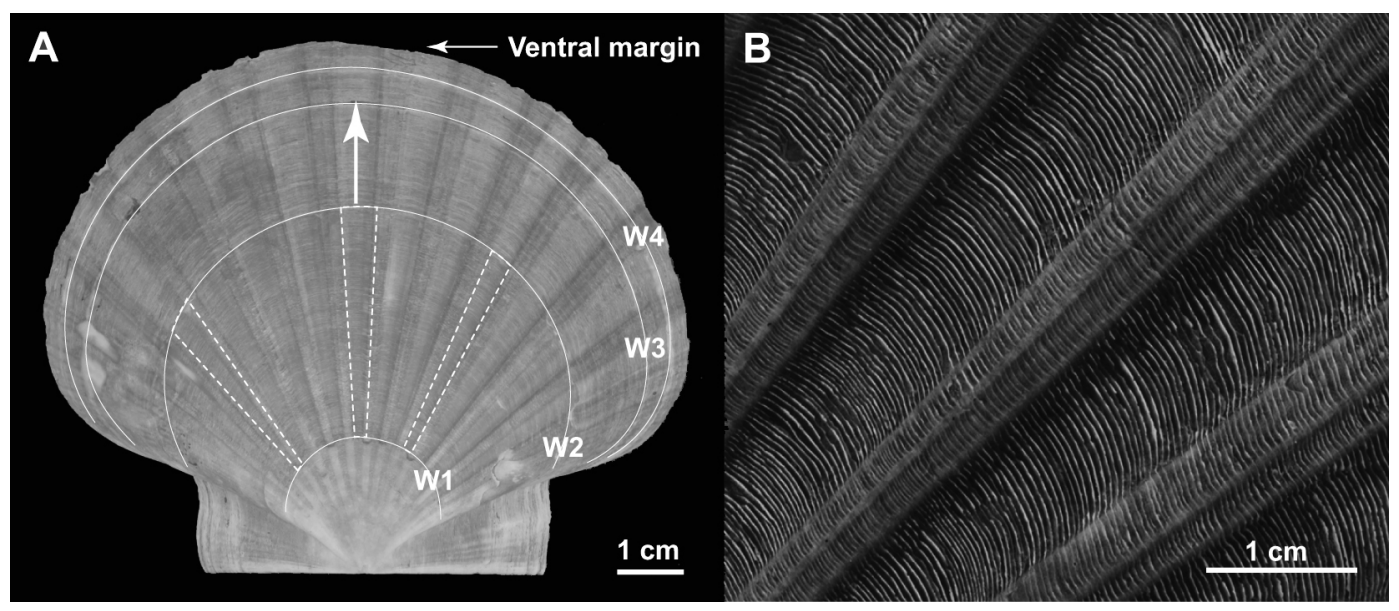

Figure 1: (A) Upper surface of the left valve of Pecten maximus. W1-W4 correspond to winter marks deposited during spring growth restart. Dashed areas indicate the different sections analysed for elemental concentrations in shell \#6. White arrow is the axis of maximum shell growth. (B) Daily growth increments can be observed without any treatment aside from surface cleaning.

son, 2001). In this context, biological records of environmental variability appear as the best way of extending conventional records related to phytoplankton dynamics over long time periods. These biological records are obtained by deciphering environmental proxies incorporated within biogenic archives during their growth (e.g., corals, sclerosponges, mollusc shells). These organisms form their external calcium carbonate $\left(\mathrm{CaCO}_{3}\right)$ skeleton periodically, which leads to the formation of growth lines that can be used as chronological landmarks.

Many of the processes occurring in these highly dynamic coastal oceans take place on short time scales, ranging from days to weeks: this is especially true for phytoplankton dynamics. Corals and sclerosponges provide useful data on past ecological variability at a seasonal time scale, at most, but they are not suited to reconstruction of past phytoplankton dynamics. On another hand, bivalve mollusc shells have an outstanding potential for high-resolution palaeoecological studies because (i) most of them form distinct daily growth structures and, therefore, provide information on high-frequency variations of palaeoenvironmental conditions, (ii) many species grow very fast (tens to hundreds of $\mu \mathrm{m} \mathrm{d}^{-1}$ ), and (iii) some bivalves have a lifespan of many centuries. For instance, bivalve mollusc shell analysis recently led to palaeoenvironmental reconstructions of seawater temperature (Schöne et al., 2011), oceanic circulation (Wanamaker Jr. et al., 2008), climatic oscillations such as North Atlantic Oscillation or El Niño Southern Oscillation (Schöne et al., 2003; Carré et al., 2005), or pollution (Gillikin et al., 2005).

Surprisingly, and despite many efforts to assess the potential of these shells as high-resolution palaeoproductivity archives, no straightforward relationship has ever been found between isotopic or elemental composition of shells and phytoplankton dynamics in seawater. Attempts to use the carbon isotope composition $\left(\delta^{13} \mathrm{C}_{\text {shell }}\right)$ as a palaeoproductivity proxy have not been successful, partly because a large part of the carbon required for mollusc shell calcification originates from the bivalve metabolism (Lorrain et al., 2004; McConnaughey and Gillikin, 2008). However, a recent study suggested that variations of this geochemical variable in shells of the great scallop Pecten maximus reflected food availability (including phytoplankton cells), which may be useful for ecophysiological studies (Chauvaud et al., 2011). In the past decade, sharp peaks have been observed in ontogenetic profiles of $\mathrm{Ba} / \mathrm{Ca}$ ratio in some bivalve shells (Stecher et al., 1996; Vander Putten et al., 2000; Lazareth et al., 2003; Gillikin et al., 2006, 2008; Barats et al., 2009; Thébault et al., 2009a). Several of these studies suggested a linkage between phytoplankton biomass (especially diatoms) and barium incorporation into the shell structure. However, many bivalve species do not display such relationships, suggesting that factors controlling variations of $\mathrm{Ba} / \mathrm{Ca}$ in shells are numerous and complex, so that it cannot be considered as a universal proxy for phytoplankton dynamics (Gillikin et al., 2008). Finally, two recent studies suggested that Mo/Ca may be used as a proxy for spring productivity in coastal ecosystems (Thébault et al., 2009a; Barats et al., 2010), but this barely studied element must be investigated in other bivalve species to confirm this hypothesis. Aside from Ba and Mo, an important set of elements was analysed by our research group in shells of Pecten maximus from the bay of Brest, France. Amongst them, lithium presented very intriguing time series that evoked patterns of phytoplankton dynamics in the bay.

Lithium has barely been investigated in marine biocarbonates. Most studies dealt with foraminifera where $\mathrm{Li} / \mathrm{Ca}$ ratio was suggested to be a proxy either for temperature, for $\mathrm{Li} / \mathrm{Ca}$ ratio in seawater, or for oceanic carbonate ion concentration (Delaney et al., 1985; Hall and Chan, 2004; Marriott et al., 2004b; Hathorne and James, 2006). The only known study dealing with $\mathrm{Li} / \mathrm{Ca}$ in bivalves was performed on aragonitic shells of the ocean quahog Arctica islandica (Thébault et al., 2009b). It was suggested that calcification rate and/or river inputs of Li-rich silicate particles were likely the main factors controlling incorporation of $\mathrm{Li}$ in shell aragonite. However, the relatively low shell growth rates of Arctica islandica prevented thorough investigations of high-frequency variations of $\mathrm{Li} / \mathrm{Ca}$.

Conversely, Pecten maximus is a very interesting species 
because of its very high shell growth rate (up to 350-400 $\mu \mathrm{m} \mathrm{d}^{-1}$ ), its lifespan (up to 12 years), and the production of clearly visible annual and daily growth lines, called striae (Chauvaud et al., 1998; Figure 1). Moreover, this species has a wide biogeographical distribution, extending from southern Morocco to the Lofoten Islands (Norway), including the Mediterranean Sea (Malaga). Its is especially abundant all along the French, Irish, British and Scottish coasts, and can be found between 0 and $500 \mathrm{~m}$ water depth (Chauvaud et al., 2005). Finally, its shell is composed of foliated calcite (Larvor et al., 1996) and is relatively immune to dissolution and recrystallization (Hickson et al., 1999), thus offering good opportunities for assessing palaeoenvironmental conditions.

The aims of this paper are (i) to analyse time series of $\mathrm{Li} / \mathrm{Ca}$ variations in shells of Pecten maximus over several years between 1999 and 2007 in the bay of Brest, (ii) to compare these variations to environmental data obtained from a high-frequency monitoring station located close to our study site, (iii) to review the different processes that may explain incorporation of $\mathrm{Li}$ in shell calcite, and (iv) to assess the potential of $\mathrm{Li} / \mathrm{Ca}_{\text {shell }}$ enrichments as proxies for phytoplankton dynamics.

\section{Material and methods}

\subsection{Study area}

Our study site, the Roscanvel bank, is located in the bay of Brest (Brittany, northwest France; Figure 2), a semienclosed marine ecosystem of $180 \mathrm{~km}^{2}$ connected to shelf waters (Iroise Sea) by a narrow and deep strait $(2 \mathrm{~km}$ width, $40 \mathrm{~m}$ depth). This bay is a shallow basin with an average depth of $8 \mathrm{~m}$. Two rivers, the Aulne (catchment area $=1792 \mathrm{~km}^{2}$ ) and the Elorn (catchment area $=379 \mathrm{~km}^{2}$ ), are responsible for up to $80 \%$ of the total freshwater input in the bay. Both catchements are composed of proterozoic and palaeozoic sedimentary rocks (shales and sandstones), punctuated with some more recent granite intrusions. Tidal amplitudes reach $8 \mathrm{~m}$ during spring tides, resulting in an oscillating volume that is $40 \%$ of the high tide volume; this induces short-term variability in hydrographic parameters and mixing of water masses (Chauvaud et al., 2005).

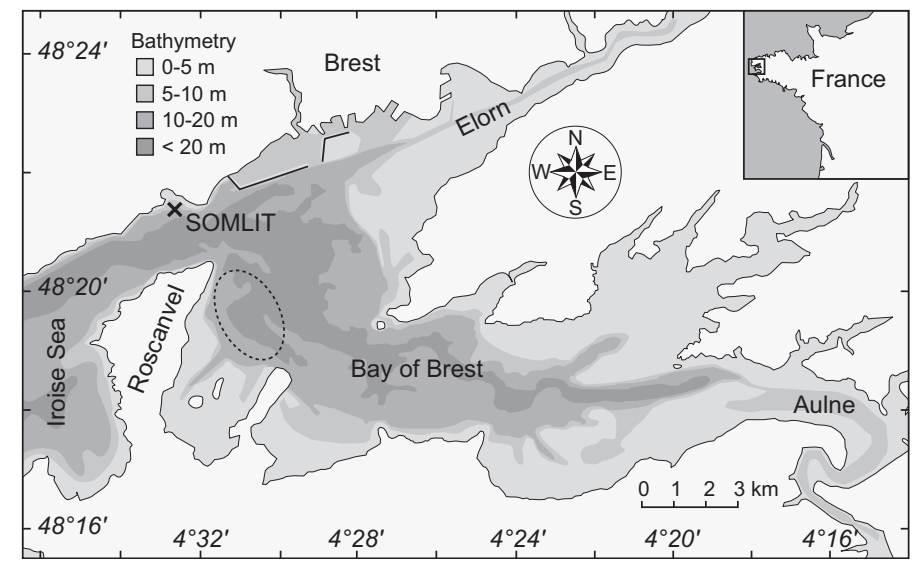

Figure 2: Shell sampling location in the Bay of Brest, northwest France (Roscanvel bank: dashed ellipse) and SOMLITBrest water monitoring station (black cross).
The Roscanvel bank (30 m water depth), is located in the western part of the bay of Brest (Figure 2). It is characterized by mixed sandy and silty sediments, and is known to host a large population of great scallop Pecten maximus. The Roscanvel bank has marine characteristics as bottomwater salinity only decreases down to 32.5 during winter flood tides, whereas it is quite stable (34-35) from spring to fall, ie. when scallops accrete calcite (Chauvaud et al., 1998).

\subsection{Environmental parameters}

Environmental parameters were monitored weekly from 1999 to 2007 at the SOMLIT-Brest station located at the outlet of the bay (Figure 2). Water sampling and measurements were performed at $1 \mathrm{~m}$ depth at slack high tide in mean tidal conditions, in order to favour the oceanic signal more than the influence of riverine inputs. Temperature and salinity were measured with a Sea-Bird SBE 19 CTD profiler (Sea-Bird Electronics, Inc.). For the determination of chlorophyll $a$ concentration, 1 L of seawater collected using a Niskin bottle was filtered onto Whatmann GF/F filters. The analysis was done according to Yentsch and Menzel (1963) using a calibrated Turner 111 fluorometer. Water samples for phytoplankton species determination were preserved in Lugol's solution. Species were identified and counted by examination on an inverted microscope. Unfortunately, no information is available on phytoplankton community composition over the period 2005-2007, thus preventing comparison of $\mathrm{Li} / \mathrm{Ca}_{\text {shell }}$ with in situ biological data.

Temperature and salinity measured at SOMLIT-Brest are known to reflect very precisely environmental conditions at Roscanvel bank (Lorrain, 2002). On another hand, there are some differences in the composition of phytoplankton communities and timing of blooms between both stations; if blooms of dominant diatom and dinoflagellate species occur approximately at the same time at SOMLIT-Brest and Roscanvel, their intensities could differ significantly. Moreover, many minor species observed at SOMLIT-Brest are typically oceanic and are not found at Roscanvel. Consequently, we only considered cell counts for diatom species (i) that are known to be dominant species at Roscanvel (Chauvaud et al., 1998; Lorrain et al., 2000), and (ii) that represented more than $10 \%$ of total diatom counts at SOMLITBrest over the period 1999-2004. The same strategy was applied to dinoflagellates. Therefore, we used counts of Chaetoceros spp. (30\% of total diatoms), Dactyliosolen fragilissimus (formerly Rhizosolenia fragilissima; 10\%), Guinardia delicatula (formerly Rhizosolenia delicatula; 17\%), and Pseudo-nitzschia spp. (10\%). All together, these species represented two thirds of diatoms counted at SOMLIT-Brest between 1999 and 2004. As for dinoflagellates, Gymnodinium spp. represented $60 \%$ of total dinoflagellates between 1999 and 2004.

\subsection{Shell sampling and growth measurements}

Live scallops were collected from Roscanvel bank using SCUBA diving. Individuals of age class I (ie. specimens that have lived only one $1^{\text {st }}$ of January) were sampled on 21 November 2001 ( $n=3$ shells born in 2000), on 3 September 2004 ( $n=3$ shells born in 2003) and on 5 November 2007 ( $n$ 
$=4$ shells born in 2006). For all these specimens, we analysed the part of the shell between the first winter growth mark and the ventral margin. This portion corresponded to shell material formed in 2001, 2004, and 2007, respectively (ie. during the second year of growth). In addition, age class III specimens were collected on 23 March 2001 ( $n=$ 3 shells born in 1998). For these three individuals, we analysed shell material located between the first and the second winter growth mark, ie. calcite formed in 1999. Analysis of shell material formed between the first and the second winter growth mark was chosen because this second year of growth corresponds to the longest annual growth season, and thus provides the longest annual calcitic record (Figure 1). In the bay of Brest, scallops in their second year grow from late March-early April to November (Chauvaud et al., 1998).

Before shell growth and elemental analyses, the upper surface of the left valves was cleaned by soaking for 3 minutes in $90 \%$ acetic acid. They were then rinsed by deionized water and air-dried. Daily shell growth rates (DSGR) were determined by measuring distances between successive daily growth striae along the axis of maximum growth using the image analysis method described by Chauvaud et al. (1998). On the basis of the daily rhythm of striae formation, absolute dates of precipitation were assigned to each stria by backdating from the last deposited stria at the day of collection (see Chauvaud et al. (2005) for elaboration).

\subsection{Elemental analyses}

Using a micromilling device (New Wave Research) equipped with a 300- $\mu \mathrm{m}$ tungsten carbide drill bit, calcite powder was milled directly from the upper surface of the left valve of the shells, along the axis of maximum growth. One stria was milled every three striae, a sampling strategy corresponding to ca. two calcite samples per week of shell growth (sub-weekly resolution). Sample preparation and analyses were performed at the Pôle Spectrométrie Océan (Plouzané, France). All samples were prepared in a class 10000 clean laboratory. Ultra-pure deionized water (resistivity = $18.2 \mathrm{M} \Omega . \mathrm{cm}$ ) was used for material cleaning and acid dilutions. Nitric acid solutions (commercial grade, Merck) were purified by distillation in sub-boiling silica glass stills (Quartex). All material (polypropylene centrifuge tubes, disposable pipette tips, etc.) was pre-cleaned using $5 \% \mathrm{HNO}_{3}$ and rinsed with ultra-pure deionized water.

A known weight of each shell sample (average weight = $127 \mu \mathrm{g}$ ) was transferred into a pre-cleaned polypropylene centrifuge tube, dissolved in $2 \% \mathrm{HNO}_{3}$, and spiked with a known amount (about $7 \mu \mathrm{L}$ ) of a mono-elemental thulium solution $\left(\mathrm{Tm}\right.$ concentration $=77.9 \mathrm{ng} \mathrm{g}^{-1}$ ). Thulium was used as an internal standard to correct short- and longterm instrumental drift (see Barrat et al. (1996) and Bayon et al. (2009) for detailed information on this method). External calibration was performed using an in-house multielement solution prepared from certified stock solutions. This calibration solution was prepared so that it closely matched the calcium carbonate matrix and elemental composition of mollusc shells.

Elemental concentrations were measured on a Thermo Electron Element2 high-resolution inductively coupled plasma mass spectrometer equipped with an ASX 260 autosampler (CETAC Technologies). Solutions were introduced via a Teflon nebulizer and a Peltier cooled cyclonic spray chamber. The Element 2 was equipped with a glass injector and a set of nickel sampler and skimmer cones. Along the course of this study, plasma power ranged between 1270 and $1310 \mathrm{~W}$ and argon flow rates were $16.06 \mathrm{~L} \mathrm{~min}^{-1}$ (cooling gas), 0.54-0.65 $\mathrm{L} \mathrm{min}^{-1}$ (auxiliary gas), and 0.95-1.35 $\mathrm{L} \mathrm{min}^{-1}$ (nebulizer gas). The Element2 was operated in medium resolution $(m / \Delta m=4000)$ and measured isotopes were ${ }^{7} \mathrm{Li}$ and ${ }^{43} \mathrm{Ca}$ (among other elements not presented in this article). Concentrations were calculated using the Tm addition method. Details on the calculations can be found in Bayon et al. (2009). Briefly, for each sample, elemental concentrations were calculated using the sample mass, the amount of Tm added, and by calibrating the raw data acquired during the measurement session against the unspiked (no added $\mathrm{Tm}$ ) in-house multi-element solution, run after every five samples.

Precision (degree of reproducibility) and accuracy (degree of veracity) of our procedure were controlled through analyses of (i) a certified reference material purchased from the National Research Council of Canada (FEBS-1: red snapper Lutjanus campechanus saggital otolith; certified values in Sturgeon et al., 2005), and (ii) a Pecten maximus in-house reference material (left valve of a specimen from the bay of Brest, crushed and carefully homogenized). Repeated measurements of these reference materials yielded a precision (relative standard deviation) of $2.05 \%$ (average

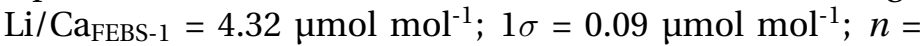
12) and $7.76 \%$ (average Li $/ \mathrm{Ca}_{\text {Pecten }}=22.50 \mu \mathrm{mol} \mathrm{mol}^{-1} ; 1 \sigma$ $\left.=1.75 \mu \mathrm{mol} \mathrm{mol}{ }^{-1} ; n=109\right)$. Accuracy was extremely good with a $\mathrm{Li}$ concentration value in FEBS- 1 of $0.304 \pm 0.007 \mathrm{mg}$ $\mathrm{kg}^{-1}$ (mean \pm standard deviation) compared with the recommended value of $0.305 \pm 0.044 \mathrm{mg} \mathrm{kg}^{-1}$. Our method slightly overestimated Ca concentration (+ $6 \%$ ) with a measured value in FEBS-1 of $407000 \pm 9000 \mathrm{mg} \mathrm{kg}^{-1}$ (mean \pm standard deviation) compared with the recommended value of $383000 \pm 14000 \mathrm{mg} \mathrm{kg}^{-1}$.

In order to check the reproducibility of $\mathrm{Li} / \mathrm{Ca}_{\text {shell }}$ ratios along a given shell, one specimen collected on 5 November 2007 (shell \#6) was also analysed for elemental content along three different axes of shell growth: the central axis (ie. axis of maximum shell growth), an axis on the left side of the shell, and another one on the right side.

\subsection{Statistical analyses}

Differences in $\mathrm{Li} / \mathrm{Ca}_{\text {shell }}$ ratios between left, central and right axes of shell \#6 were tested with an analysis of variance after verification of homoscedasticity with Bartlett's test $(\alpha=0.01)$. Tukey HSD (Honestly Significant Difference) post-hoc test was used to identify which axis differed from the other ones. Simple and multiple linear regressions were performed between $\mathrm{Li} / \mathrm{Ca}_{\text {shell }}$ and possible explanatory variables (seawater temperature, salinity, chlorophyll a concentration, and daily shell growth rate) for each single year (1999, 2001, 2004, and 2007) and for the whole dataset (1999-2007). Before performing multivariate regressions, we used the Schwartz's Bayesian Information Criterion (BIC) to select the best subset of explanatory variables. Finally, a model II regression was used to fit $\mathrm{Li} / \mathrm{Ca}_{\text {shell }}$ 

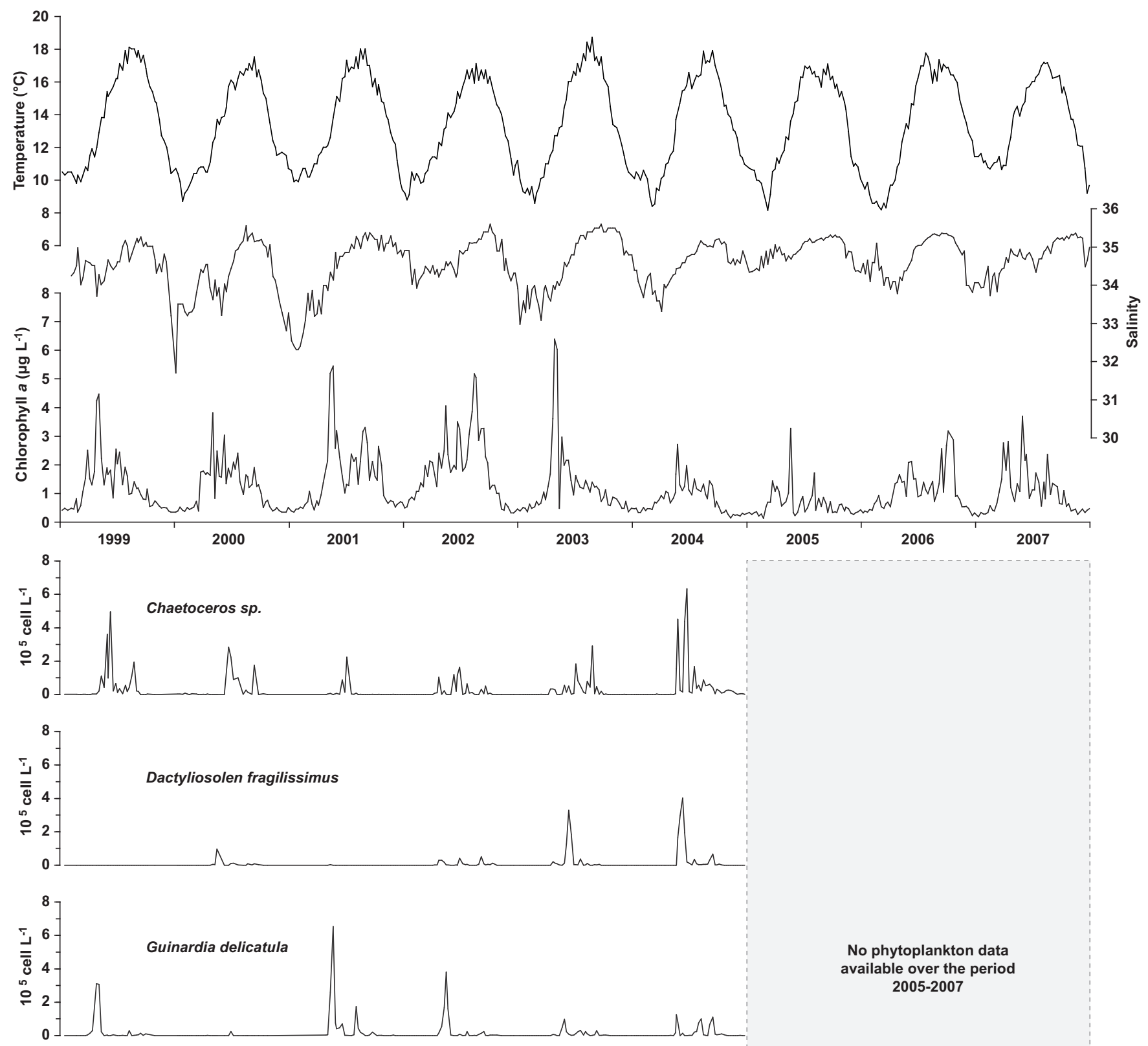

No phytoplankton data available over the period 2005-2007
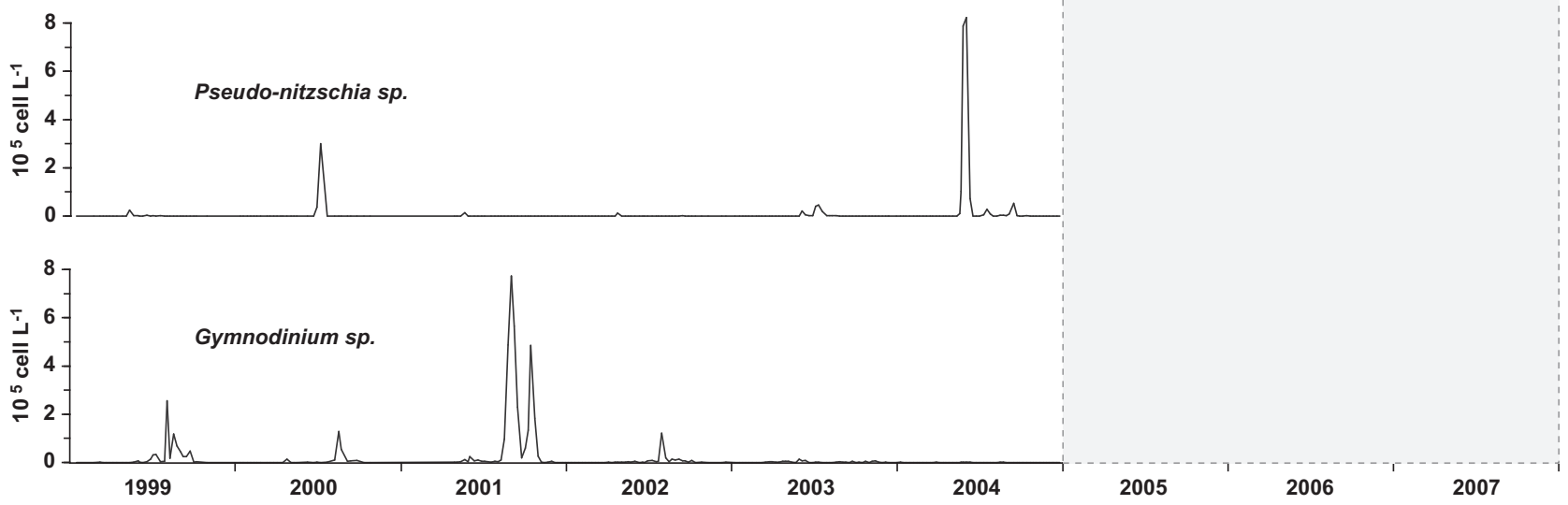

Figure 3: Variations of physical (temperature, salinity) and biological (chlorophyll $a$ concentration, phytoplankton counts) parameters recorded at the SOMLIT-Brest monitoring station from 1999 to 2007. Note that phytoplankton counts are not available between 2005 and 2007. 
and DSGR (Standard Major Axis). All statistical analyses were performed with R, using "leaps" (for BIC model selection criteria) and "lmodel2" (for model II regressions) packages.

\section{Results}

\subsection{Variability of environmental parameters between 1999 and 2007}

Temperature variations at SOMLIT-Brest displayed a clear seasonal signal over the study period, with an annual temperature range from $8.0^{\circ} \mathrm{C}$ in 2007 to $10.1^{\circ} \mathrm{C}$ in 2003 (Figure 3). Water temperature was lowest between mid-January and mid-March (mean 1999-2007 $=8.8^{\circ} \mathrm{C} ; \sigma=0.6^{\circ} \mathrm{C}$ ) and reached a maximum in August-September (mean 1999$2007=17.7^{\circ} \mathrm{C} ; \sigma=0.5^{\circ} \mathrm{C}$ ). Over the same period, there were minor fluctuations in surface salinity, usually ranging between 33 and 35.6. Salinity drops during winter and early spring corresponded with increases in Aulne and Elorn flows. Exceptional surface salinity decreases were recorded in January 2000 (31.7) and January 2001 (32.3). These quite low salinities were likely restricted to surface waters and did not influence scallops in Roscanvel bottom water. Intraannual salinity ranges varied from 0.97 in 2005 to 3.84 in 2000 . These temperature and salinity values were very similar to bottom-water values measured at Roscanvel by Chauvaud et al. (1998).

Chlorophyll $a$ concentration ranged from $0.12 \mu \mathrm{L} \mathrm{L}^{-1}$ in February 2005 to $6.39 \mathrm{\mu g} \mathrm{L}^{-1}$ in April 2003 (Figure 3). Largest annual phytoplankton blooms were recorded in May, except in 2002 (maximum concentration in August) and in 2006 (maximum concentration in October), with varying intensities depending on the year (from $2.70 \mu \mathrm{L}^{-1}$ in 2004 to $6.39 \mu \mathrm{g} \mathrm{L}^{-1}$ in 2003). The mean chlorophyll $a$ value was $1.2 \mu \mathrm{g} \mathrm{L}^{-1}$ over the study period. This value masked some inter-annual variations, especially in 2002 (highest mean annual concentration of $1.8 \mu \mathrm{g} \mathrm{L}^{-1}$ ) and in 2005 (lowest mean annual concentration of $0.6 \mu \mathrm{g} \mathrm{L}^{-1}$ ).

Most of this chlorophyll $a$ was contained within cells of the diatom genus Chaetoceros (Figure 3). This genus was present in the water column every year, with concentrations reaching 634670 cell L$^{-1}$ on 22 June 2004. Highest abundances were recorded in 1999 and 2004, whereas 2001 was characterized with only two small blooms $(<250$ 000 cell L $^{-1}$ ). Another abundant diatom, Dactyliosolen fragilissimus, displayed important blooms at SOMLIT-Brest in 2003 and 2004 (up to 402730 cell L-1 on 8 June 2004). This species presented very low levels from 1999 to $2002(<100$ 000 cell L $\left.^{-1}\right)$. The diatom Guinardia delicatula formed large

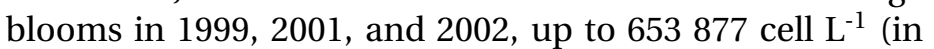
May 2001), but displayed low levels in 2000, 2003, and 2004 $\left(<150000\right.$ cell L $\left.^{-1}\right)$. The fourth genus of diatoms abundant at SOMLIT-Brest was Pseudo-nitzschia. These species were usually not present in the water column, except in July 2000 and in May 2004 when they formed a very large bloom up to 822931 cell L $^{-1}$. One dinoflagellate genus, Gymnodinium, presented quite high levels between 1999 and 2002, with two large blooms in late August (773 478 cell L $^{-1}$ ) and midOctober 2001 (486 388 cell L $^{-1}$ ). It should be mentioned that another dinoflagellate species, Karenia mikimotoi (formerly Gymnodinium nagasakiense), represented $23 \%$ of total dinoflagellates at SOMLIT-Brest, because of a unique large bloom in August 2002 (678 321 cell L $^{-1}$ ). Finally, maximum chlorophyll $a$ concentrations recorded in 2000 and 2003 were related to diatom blooms of Thalassiosira spp. (196 997 cell L $^{-1}$ on 2 May 2000; 5\% of total diatoms at SOMLIT-Brest) and Cerataulina pelagica (444 357 cell L $^{-1}$ on 28 April 2003; 4\% of total diatoms).

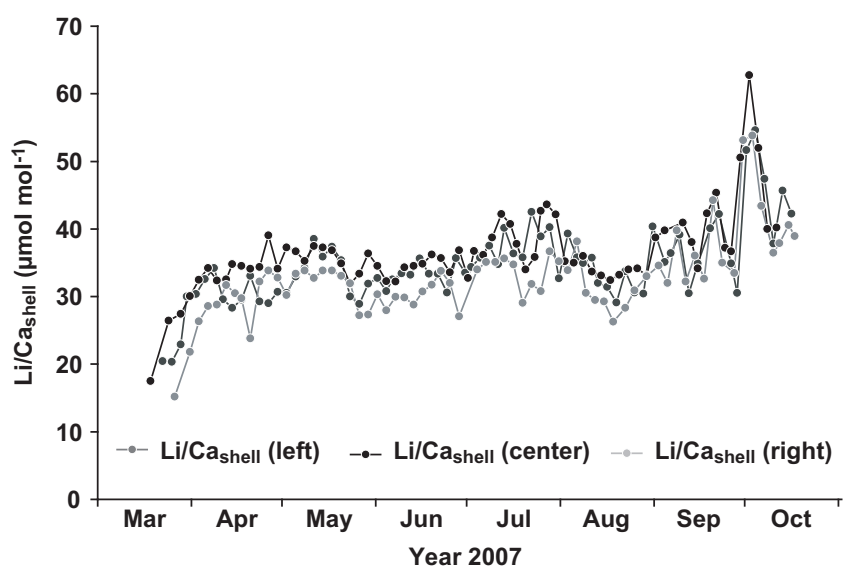

Figure 4: Temporal variations of $\mathrm{Li} / \mathrm{Ca}$ ratios along left, central, and right axes of growth of shell \#6 collected on 5 November 2007.

\section{2. $\mathrm{Li} / \mathrm{Ca} a_{\text {shell }}$ time series and daily shell growth rate}

$\mathrm{Li} / \mathrm{Ca}_{\text {shell }}$ ratio time series along the three axes of growth were remarkably similar, with highest ratios recorded at the same time between 2 October 2007 and 4 October 2007 (Figure 4). Average $\mathrm{Li} / \mathrm{Ca}_{\text {shell }}$ ratio on left, central, and right axis were $34.54 \mu \mathrm{mol} \mathrm{mol}^{-1}\left(\sigma=5.81 \mu \mathrm{mol} \mathrm{mol}^{-1}\right), 36.40$ $\mu \mathrm{mol} \mathrm{mol}^{-1}\left(\sigma=5.83 \mu \mathrm{mol} \mathrm{mol}^{-1}\right)$, and $32.79 \mu \mathrm{mol} \mathrm{mol}^{-1}(\sigma=$ $\left.5.86 \mathrm{umol} \mathrm{mol}^{-1}\right)$, respectively. These small differences were statistically significant (Bartlett's test: $\chi^{2}$ Bartlett $=0.006, d f=$ $2, p=0.997$; ANOVA: $F=6.56, d f=2$ and 206, $p=0.002$ ); post-hoc test indicated that average $\mathrm{Li} / \mathrm{Ca}_{\text {shell }}$ ratio on the right axis was significantly lower than on the central axis.

Temporal variations of $\mathrm{Li} / \mathrm{Ca}_{\text {shell }}$ displayed a high degree of synchronism (inter-individual reproducibility), whatever the year (Figure 5). On another hand, $\mathrm{Li} / \mathrm{Ca}_{\text {shell }}$ showed very different trajectories in 1999, 2004, and in 2001 and 2007. In 1999, all three specimens presented a kind of exponential increase in $\mathrm{Li} / \mathrm{Ca}_{\text {shell }}$ from ca. $20 \mu \mathrm{mol} \mathrm{mol}^{-1}$ in March to $190-250 \mu \mathrm{mol} \mathrm{mol}{ }^{-1}$ (depending on the specimen) between 2 July 1999 and 4 July 1999 . $\mathrm{Li} / \mathrm{Ca}_{\text {shell }}$ then decreased down to values around $30-40 \mu \mathrm{mol} \mathrm{mol}{ }^{-1}$ at the end of July and stayed at this level until December. In 2004, $\mathrm{Li} / \mathrm{Ca}_{\text {shell }}$ presented values around $30-40 \mu \mathrm{mol} \mathrm{mol}{ }^{-1}$, except from the end of May to the end of July. During that period, all three specimens displayed a high degree of synchronism, presenting the same profiles punctuated with three main $\mathrm{Li} / \mathrm{Ca}_{\text {shell }}$ peaks at the beginning of June (90-95 $\left.\mathrm{mol} \mathrm{mol}^{-1}\right)$, at the end of June (90-100 $\mathrm{mol} \mathrm{mol}^{-1}$ ), and in mid-July (65$75 \mu \mathrm{mol} \mathrm{mol}^{-1}$ ). In 2001 and $2007, \mathrm{Li} / \mathrm{Ca}_{\text {shell }}$ values fluctuated between 15 and $50 \mu \mathrm{mol} \mathrm{mol}{ }^{-1}$ all year long, except a little sharp peak around $65-70 \mu \mathrm{mol} \mathrm{mol}^{-1}$ at the beginning of October 2007 on the four studied specimens. Given the very low inter-individual variability in $\mathrm{Li} / \mathrm{Ca}_{\text {shell }}$ and the sharpness of $\mathrm{Li} / \mathrm{Ca}_{\text {shell }}$ peaks, it is likely that the latter resulted from transient phenomenons in the water column (environmental forcing). 
Table 1: Annual minimum, maximum, and mean values of $\mathrm{Li} / \mathrm{Ca}_{\text {shell }}$ and daily shell growth rate of each Pecten maximus specimen analyzed over the period 1999-2007.

\begin{tabular}{|c|c|c|c|c|c|c|c|}
\hline \multirow{2}{*}{ Year } & \multirow{2}{*}{ Shell } & \multicolumn{3}{|c|}{$\mathrm{Li} / \mathrm{Ca}_{\text {shell }}\left(\mu \mathrm{mol} \mathrm{mol}{ }^{-1}\right)$} & \multicolumn{3}{|c|}{$\operatorname{DSGR}\left(\mu \mathrm{m} \mathrm{d}^{-1}\right)$} \\
\hline & & Min. & Mean & Max. & Min. & Mean & Max. \\
\hline \multirow{3}{*}{1999} & $\# 103$ & 19.05 & 50.03 & 243.83 & 40.66 & 202.32 & 329.29 \\
\hline & $\# 105$ & 17.02 & 50.79 & 191.22 & 86.17 & 229.91 & 377.09 \\
\hline & $\# 106$ & 16.48 & 48.53 & 202.28 & 45.08 & 176.69 & 307.64 \\
\hline \multirow{3}{*}{2001} & $\# 5$ & 14.87 & 28.86 & 43.09 & 42.17 & 176.34 & 298.25 \\
\hline & $\# 10$ & 19.90 & 32.01 & 48.53 & 57.52 & 176.29 & 262.42 \\
\hline & $\# 12$ & 20.24 & 34.87 & 47.22 & 53.44 & 177.37 & 274.62 \\
\hline \multirow{3}{*}{2004} & $\# 1$ & 15.19 & 47.89 & 93.41 & 37.11 & 227.82 & 340.16 \\
\hline & $\# 2$ & 18.39 & 47.94 & 90.43 & 36.88 & 244.44 & 385.60 \\
\hline & $\# 3$ & 21.14 & 50.83 & 100.96 & 61.47 & 228.24 & 409.84 \\
\hline \multirow{4}{*}{2007} & $\# 5$ & 15.64 & 35.97 & 63.53 & 68.17 & 213.06 & 377.27 \\
\hline & $\# 7$ & 18.32 & 34.51 & 70.01 & 30.98 & 167.84 & 290.74 \\
\hline & $\# 666$ & 18.49 & 35.18 & 70.09 & 47.11 & 177.98 & 285.14 \\
\hline & $\# 6$ & 17.49 & 36.40 & 62.74 & 42.43 & 166.19 & 306.47 \\
\hline
\end{tabular}

Daily shell growth rate varied by an order of magnitude over a given growing season from minima around $35-50$ $\mu \mathrm{m} \mathrm{d}^{-1}$ to maxima reaching $250-350 \mu \mathrm{m} \mathrm{d}^{-1}$, with very little inter-individual variability (Figure 5). Whatever the year, shell growth restarted at the end of March after a winter growth cessation, and reached maximum values in JuneJuly. Significant differences were observed in shell growth trajectories between years. In 1999, scallops exhibited a sharp increase in DSGR from March to July, and then a slow decrease until the following winter growth cessation. Shell growth, however, was abruptly reduced in May 1999 $\left(-75 \mu \mathrm{m} \mathrm{d}^{-1}\right)$. In 2001, shell growth slightly increased from March to mid-May, suddenly dropped down to ca. $90 \mu \mathrm{m}$ $\mathrm{d}^{-1}$ at the end of May, abruptly increased to reach maxima in July, and then slowly decreased until November. The latter decrease was punctuated with a growth retardation in September 2001. Shell growth trajectory was quite similar in 2001 and 2004, at least until the end of August. No data were available after August 2004 as shells were collected before the end of the growing season. Finally, in 2007, DSGR sharply increased from $35 \mu \mathrm{m} \mathrm{d}^{-1}$ in March to ca. $220 \mu \mathrm{m}$ $\mathrm{d}^{-1}$ in April, and stayed around $150-250 \mu \mathrm{m} \mathrm{d}^{-1}$ until October (except at the end of May 2007 when a sudden decrease down to $100 \mu \mathrm{m} \mathrm{d}^{-1}$ was observed). Note that all geochemical and shell growth data obtained on each of the 13 specimens analysed in this study can be retrieved in Table 1 .

Table 2: Summary of simple and multiple linear regressions performed with $\mathrm{Li} / \mathrm{Ca}_{\text {shell }}$ as response variable, and seawater temperature, salinity, chlorophyll $a$ concentration and daily shell growth rate as explanatory variables.

\begin{tabular}{|c|c|c|c|c|c|c|c|}
\hline & Estimate & Std. error & $T$ & $p$-value & $F$-statistic & Adjusted $r^{2}$ & $p$-value \\
\hline \multicolumn{8}{|c|}{ Year 1999} \\
\hline $\begin{array}{l}\text { Temperature } \\
\text { Intercept }\end{array}$ & $\begin{array}{c}3.57 \\
-3.57\end{array}$ & $\begin{array}{c}2.83 \\
43.58\end{array}$ & $\begin{array}{c}1.261 \\
-0.082\end{array}$ & $\begin{array}{l}0.216 \\
0.935\end{array}$ & 1.59 on 1 and $32 d f$ & 0.018 & 0.216 \\
\hline $\begin{array}{l}\text { Salinity } \\
\text { Intercept }\end{array}$ & $\begin{array}{c}-6.44 \\
274.36\end{array}$ & $\begin{array}{c}17.21 \\
597.17\end{array}$ & $\begin{array}{c}-0.374 \\
0.459\end{array}$ & $\begin{array}{l}0.711 \\
0.649\end{array}$ & 0.14 on 1 and $32 d f$ & -0.027 & 0.711 \\
\hline $\begin{array}{l}\text { Chlorophyll a } \\
\text { Intercept }\end{array}$ & $\begin{array}{c}9.52 \\
37.23\end{array}$ & $\begin{array}{c}6.45 \\
11.01\end{array}$ & $\begin{array}{l}1.475 \\
3.382\end{array}$ & $\begin{array}{l}0.150 \\
0.002\end{array}$ & 2.18 on 1 and $32 d f$ & 0.034 & 0.150 \\
\hline $\begin{array}{l}\text { DSGR } \\
\text { Intercept }\end{array}$ & $\begin{array}{c}0.40 \\
-24.92\end{array}$ & $\begin{array}{c}0.10 \\
19.09\end{array}$ & $\begin{array}{c}4.113 \\
-1.305\end{array}$ & $\begin{array}{r}<0.001 \\
0.201\end{array}$ & 16.92 on 1 and $32 d f$ & 0.325 & $<0.001$ \\
\hline $\begin{array}{l}\text { DSGR } \\
\text { Temperature } \\
\text { Intercept }\end{array}$ & $\begin{array}{c}0.55 \\
-5.22 \\
27.25\end{array}$ & $\begin{array}{c}0.13 \\
3.06 \\
35.81\end{array}$ & $\begin{array}{c}4.286 \\
-1.703 \\
0.761\end{array}$ & $\begin{array}{r}<0.001 \\
0.099 \\
0.452\end{array}$ & 10.41 on 2 and $31 d f$ & 0.363 & $<0.001$ \\
\hline \multicolumn{8}{|c|}{ Year 2001} \\
\hline $\begin{array}{l}\text { Temperature } \\
\text { Intercept }\end{array}$ & $\begin{array}{l}2.05 \\
0.53\end{array}$ & $\begin{array}{l}0.33 \\
4.99\end{array}$ & $\begin{array}{l}6.255 \\
0.107\end{array}$ & $\begin{array}{r}<0.001 \\
0.916\end{array}$ & 39.12 on 1 and $30 d f$ & 0.552 & $<0.001$ \\
\hline $\begin{array}{l}\text { Salinity } \\
\text { Intercept }\end{array}$ & $\begin{array}{c}6.64 \\
-199.19\end{array}$ & $\begin{array}{c}1.24 \\
42.89\end{array}$ & $\begin{array}{c}5.380 \\
-4.644\end{array}$ & $\begin{array}{l}<0.001 \\
<0.001\end{array}$ & 28.94 on 1 and $30 d f$ & 0.474 & $<0.001$ \\
\hline $\begin{array}{l}\text { Chlorophyll a } \\
\text { Intercept }\end{array}$ & $\begin{array}{l}-0.25 \\
32.00\end{array}$ & $\begin{array}{l}0.91 \\
2.09\end{array}$ & $\begin{array}{l}-0.279 \\
15.289\end{array}$ & $\begin{array}{r}0.782 \\
<0.001\end{array}$ & 0.078 on 1 and $30 d f$ & -0.031 & 0.782 \\
\hline
\end{tabular}


Table 2 - Continued from previous page

\begin{tabular}{|c|c|c|c|c|c|c|c|}
\hline & Estimate & Std. error & $T$ & $p$-value & $F$-statistic & Adjusted $r^{2}$ & $p$-value \\
\hline DSGR & 0.10 & 0.01 & 9.021 & $<0.001$ & \multirow[t]{2}{*}{81.38 on 1 and $30 d f$} & \multirow[t]{2}{*}{0.722} & \multirow[t]{2}{*}{$<0.001$} \\
\hline Intercept & 14.64 & 1.94 & 7.533 & $<0.001$ & & & \\
\hline DSGR & 0.08 & 0.01 & 5.533 & $<0.001$ & \multirow[t]{3}{*}{44.06 on 2 and $29 d f$} & \multirow[t]{3}{*}{0.735} & \multirow[t]{3}{*}{$<0.001$} \\
\hline Salinity & 1.95 & 1.22 & 1.595 & 0.122 & & & \\
\hline Intercept & -50.11 & 40.64 & -1.233 & 0.228 & & & \\
\hline \multicolumn{8}{|c|}{ Year 2004} \\
\hline Temperature & 3.94 & 1.39 & 2.826 & 0.010 & \multirow[t]{2}{*}{7.99 on 1 and $20 d f$} & \multirow[t]{2}{*}{0.250} & \multirow[t]{2}{*}{0.010} \\
\hline Intercept & -8.12 & 20.13 & -0.403 & 0.691 & & & \\
\hline Salinity & 16.70 & 8.06 & 2.072 & 0.051 & \multirow{2}{*}{4.30 on 1 and $20 d f$} & \multirow[t]{2}{*}{0.136} & \multirow[t]{2}{*}{0.051} \\
\hline Intercept & -528.31 & 278.03 & -1.900 & 0.072 & & & \\
\hline Chlorophyll a & 12.94 & 9.04 & 1.432 & 0.167 & \multirow{2}{*}{2.05 on 1 and $21 d f$} & \multirow[t]{2}{*}{0.046} & \multirow[t]{2}{*}{0.167} \\
\hline Intercept & 32.46 & 11.31 & 2.871 & 0.009 & & & \\
\hline DSGR & 0.18 & 0.05 & 3.638 & 0.002 & \multirow[t]{2}{*}{13.23 on 1 and $21 d f$} & \multirow[t]{2}{*}{0.357} & \multirow[t]{2}{*}{0.002} \\
\hline Intercept & 6.94 & 11.65 & 0.596 & 0.558 & & & \\
\hline DSGR & 0.45 & 0.12 & 3.862 & 0.001 & \multirow[t]{3}{*}{11.10 on 2 and $19 d f$} & \multirow[t]{3}{*}{0.490} & \multirow[t]{3}{*}{$<0.001$} \\
\hline Salinity & -40.19 & 15.98 & -2.516 & 0.021 & & & \\
\hline Intercept & 1332.06 & 526.90 & 2.528 & 0.020 & & & \\
\hline \multicolumn{8}{|c|}{ Year 2007} \\
\hline Temperature & 1.50 & 0.68 & 2.199 & 0.037 & \multirow{2}{*}{4.83 on 1 and $25 d f$} & 0.129 & 0.037 \\
\hline Intercept & 13.44 & 10.28 & 1.307 & 0.203 & & & \\
\hline Salinity & 19.07 & 4.69 & 4.064 & $<0.001$ & 16.52 on 1 and $25 d f$ & 0.374 & $<0.001$ \\
\hline Intercept & -628.31 & 163.42 & -3.845 & $<0.001$ & & & \\
\hline Chlorophyll a & -3.96 & 1.76 & -2.254 & 0.033 & 5.08 on 1 and $25 d f$ & 0.136 & 0.033 \\
\hline Intercept & 41.62 & 2.89 & 14.427 & $<0.001$ & & & \\
\hline DSGR & 0.07 & 0.03 & 2.146 & 0.042 & 4.60 on 1 and $25 d f$ & 0.122 & 0.042 \\
\hline Intercept & 23.92 & 5.72 & 4.181 & $<0.001$ & & & \\
\hline DSGR & 0.05 & 0.03 & 2.087 & 0.048 & 11.55 on 2 and $24 d f$ & 0.448 & $<0.001$ \\
\hline Salinity & 17.69 & 4.46 & 3.971 & $<0.001$ & & & \\
\hline Intercept & -589.57 & 154.56 & -3.815 & $<0.001$ & & & \\
\hline & & & & ars 1999-2 & & & \\
\hline Temperature & 2.73 & 0.94 & 2.911 & 0.004 & 8.48 on 1 and $113 d f$ & 0.062 & 0.004 \\
\hline Intercept & 0.62 & 14.15 & 0.044 & 0.965 & & & \\
\hline Salinity & 4.45 & 4.71 & 0.944 & 0.347 & 0.89 on 1 and $113 d f$ & -0.001 & 0.347 \\
\hline Intercept & -112.90 & 163.50 & -0.691 & 0.491 & & & \\
\hline Chlorophyll a & 0.40 & 2.29 & 0.173 & 0.863 & 0.03 on 1 and $114 d f$ & -0.009 & 0.863 \\
\hline Intercept & 40.77 & 4.13 & 9.882 & $<0.001$ & & & \\
\hline DSGR & 0.21 & 0.03 & 6.539 & $<0.001$ & 42.76 on 1 and $114 d f$ & 0.266 & $<0.001$ \\
\hline Intercept & 1.42 & 6.38 & 0.223 & 0.824 & & & \\
\hline DSGR & 0.24 & 0.04 & 6.678 & $<0.001$ & 22.92 on 2 and $112 d f$ & 0.278 & $<0.001$ \\
\hline Salinity & -7.29 & 4.37 & -1.668 & 0.098 & & & \\
\hline Intercept & 249.99 & 149.14 & 1.676 & 0.097 & & & \\
\hline
\end{tabular}

3.3. Multivariate statistical analyses of $\mathrm{Li} / \mathrm{C} a_{\text {shell }}$ variations

Simple and multiple linear regressions provided interesting information on variables that may explain $\mathrm{Li} / \mathrm{Ca}_{\text {shell }}$ variations (Table 2). As inter-individual variability in $\mathrm{Li} / \mathrm{Ca}_{\text {shell }}$ time series was very low for a given growing season (Figure 5), we calculated average $\mathrm{Li} / \mathrm{Ca}_{\text {shell }}$ profiles for each year. Simple regressions performed on each year indicated that the variable with the strongest statistically significant $(p<0.05)$ relationship with average $\mathrm{Li} / \mathrm{Ca}_{\text {shell }}$ was DSGR in $1999\left(r^{2}=0.325\right)$, in $2001\left(r^{2}=0.722\right)$, and in 2004 $\left(r^{2}=0.357\right)$, and salinity in $2007\left(r^{2}=0.374\right)$. Except in $2007\left(r^{2}=0.136 ; p=0.033\right)$, chlorophyll $a$ concentration did not present a significant relationship with $\mathrm{Li} / \mathrm{Ca}_{\text {shell }}$. Seawater temperature relationship with $\mathrm{Li} / \mathrm{Ca}_{\text {shell }}$ was strong in $2001\left(r^{2}=0.552 ; p<0.001\right)$, weak albeit significant in $2004\left(r^{2}=0.250 ; p=0.01\right)$ and $2007\left(r^{2}=0.129 ; p=0.037\right)$, and non-significant in $1999\left(r^{2}=0.018 ; p=0.216\right)$. Multiple linear regressions performed for each year with the two best explanatory variables (selected using the Schwartz's Bayesian Information Criterion: DSGR and temperature in 1999; DSGR and salinity in 2001, 2004, and 2007) were all statistically significant $(p<0.001)$. However, the only variable that was always statistically significant in these models was DSGR (together with salinity in 2004 and 2007). These models explained between 36.3 and $49.0 \%$ of average $\mathrm{Li} / \mathrm{Ca}_{\text {shell }}$ variability in 1999, 2004 and 2007, suggesting that most of this variability resulted from another parameter (see discussion below on phytoplankton species). On another hand, our multivariate model explained $73.5 \%$ of $\mathrm{Li} / \mathrm{Ca}_{\text {shell }}$ variability in 2001 , ie. when no $\mathrm{Li} / \mathrm{Ca}_{\text {shell }}$ peaks 

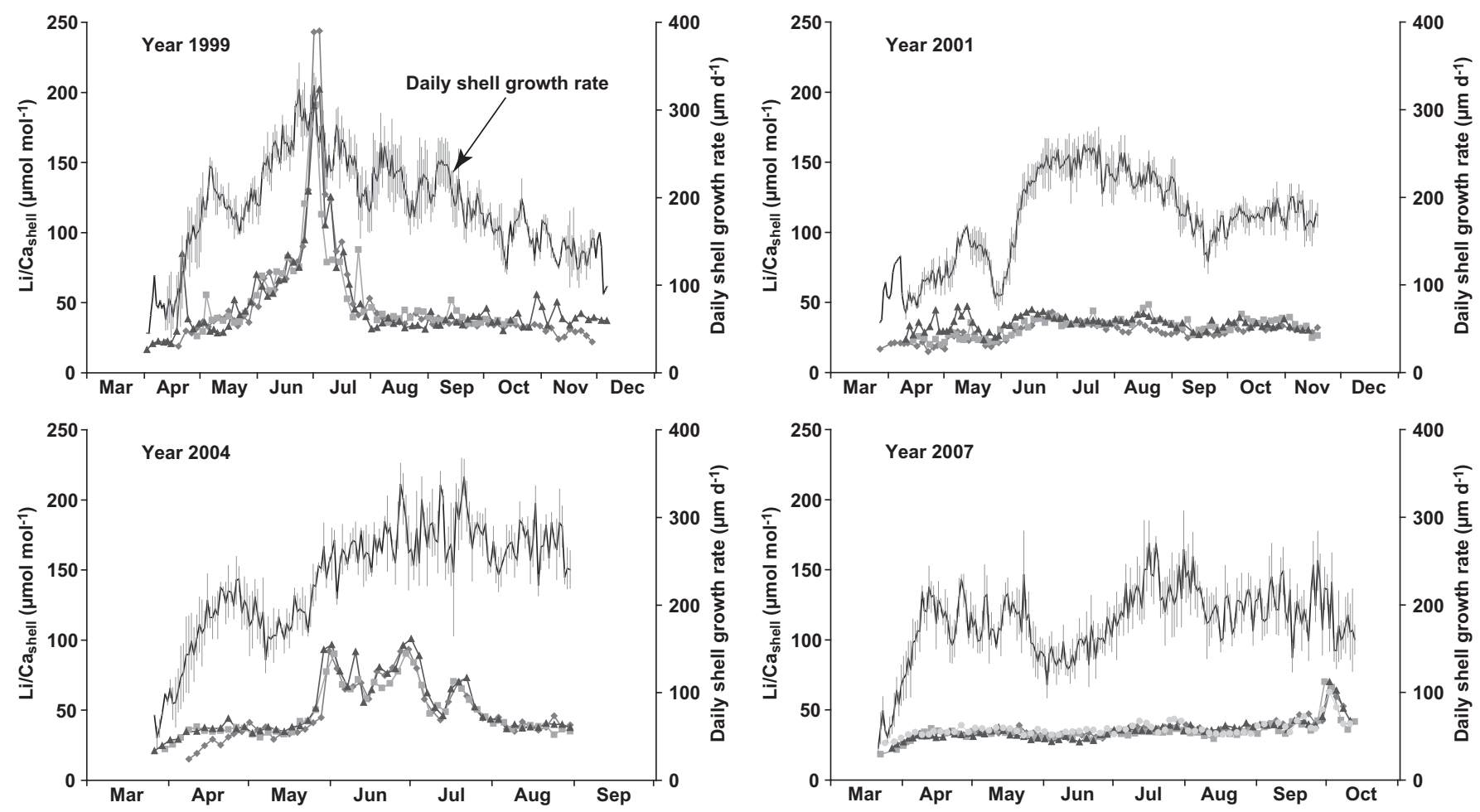

Figure 5: Time series of $\mathrm{Li} / \mathrm{Ca}_{\text {shell }}$ (greyscale symbols) and average daily shell growth rate (black line; \pm 1 standard error) in 1999 ( $n=3$ shells), $2001(n=3), 2004(n=3)$, and $2007(n=4)$.

were recorded in the shells. Most of this variability was explained by DSGR as salinity was not a significant predictor in this model $(p=0.122)$. When all years were considered as a single dataset covering the period 1999-2007, the only variables that significantly explained some part of the $\mathrm{Li} / \mathrm{Ca}_{\text {shell }}$ variability were DSGR $\left(r^{2}=0.266 ; p<0.001\right)$ and, to a lesser extent, seawater temperature $\left(r^{2}=0.062 ; p\right.$ $=0.004$ ).

Graphical outputs confirmed results of these statistical analyses. Average $\mathrm{Li} / \mathrm{Ca}_{\text {shell }}$ profiles are displayed on Figure 6 , together with average DSGR and seasonal variations of seawater temperature and salinity, ie. the three variables that could most likely explain variations of $\mathrm{Li} / \mathrm{Ca}_{\text {shell }}$ (see Table 2). We increased the vertical resolution of the $y$-axis in comparison with Figure 5 in order to get a better insight of baseline variations of $\mathrm{Li} / \mathrm{Ca}_{\text {shell }}$ time series. It appeared clearly that $\mathrm{Li} / \mathrm{Ca}_{\text {shell }}$ peaks were not induced by variations of DSGR, temperature or salinity. None of these parameters presented sharp increases or decreases synchronous with $\mathrm{Li} / \mathrm{Ca}_{\text {shell }}$ peaks (Figure 6). Therefore, the statistically significant relationships described between average $\mathrm{Li} / \mathrm{Ca}_{\text {shell }}$ variations on one hand, and DSGR, temperature or salinity on the other hand, very likely pertained to variations of baseline $\mathrm{Li} / \mathrm{Ca}_{\text {shell }}$. Outside peak periods, variations of baseline $\mathrm{Li} / \mathrm{Ca}_{\text {shell }}$ tended to follow the same pattern as seasonal variations of DSGR. This was particularly striking for shells collected in November 2001 and, to a lesser extent, in November 2007 (part of the time series between March and September 2007, ie. before the early October $\mathrm{Li} / \mathrm{Ca}_{\text {shell }}$ peak). This growth-Li/Ca $\mathrm{Call}_{\text {shell }}$ relationship was also visible on 1999 and 2004 shells, between March and May 1999, between August and December 1999, and from March to May 2004 (ie. outside the peak periods). Cross-plots of $\mathrm{Li} / \mathrm{Ca}_{\text {shell }}$ versus DSGR, established for each year, confirmed these observations (Figure 7). In 2001, ie. the year when shells did not present $\mathrm{Li} / \mathrm{Ca}_{\text {shell }}$ peaks, $\mathrm{Li} / \mathrm{Ca}_{\text {shell }}$ and DSGR presented a strong and highly significant relationship (Standard Major Axis regression, $n=237, r=0.86, p<0.001$; Figure 7). In 1999, 2004, and to a lesser extent 2007, growth- $\mathrm{Li} / \mathrm{Ca}_{\text {shell }}$ relationships, although statistically significant $(p<0.001)$, were weaker $(r \leq 0.64)$ and deviated from the relationship established in 2001. Slopes of these relationships $(0.160 \leq$ slope $\leq 0.550$ ) were higher than in 2001 (slope $=0.107$ ), reflecting the presence of $\mathrm{Li} / \mathrm{Ca}_{\text {shell }}$ peaks in 1999, 2004, and 2007 (Figure 7).

On another hand, no obvious relationship was observed between variations of baseline $\mathrm{Li} / \mathrm{Ca}_{\text {shell }}$ and variations of temperature and salinity (Figure 7). This was especially noticeable in May 2001 when $\mathrm{Li} / \mathrm{Ca}_{\text {shell }}$ decreased abruptly whereas temperature and salinity did not present any significant decrease nor abrupt increase. This confirmed equivocal results of simple and multiple linear regressions between $\mathrm{Li} / \mathrm{Ca}_{\text {shell }}$ and these two environmental variables (Table 2).

\subsection{Variations of excess $\mathrm{Li} / \mathrm{C} a_{\text {shell }}$}

In order to investigate determinism of $\mathrm{Li} / \mathrm{Ca}_{\text {shell }}$ peaks, we made the assumption that $\mathrm{Li} / \mathrm{Ca}_{\text {shell }}$ variations were mostly controlled by DSGR outside peak periods (which was confirmed by statistical analyses and graphical outputs; Table 2 and Figures 6-7). We selected data obtained on shells collected in November 2001, that did not present $\mathrm{Li} / \mathrm{Ca}_{\text {shell }}$ peaks, to derive the growth-baseline $\mathrm{Li} / \mathrm{Ca}_{\text {shell }}$ relationship:

$$
L i / C a_{\text {shell }}=0.107 \times D S G R+12.824
$$



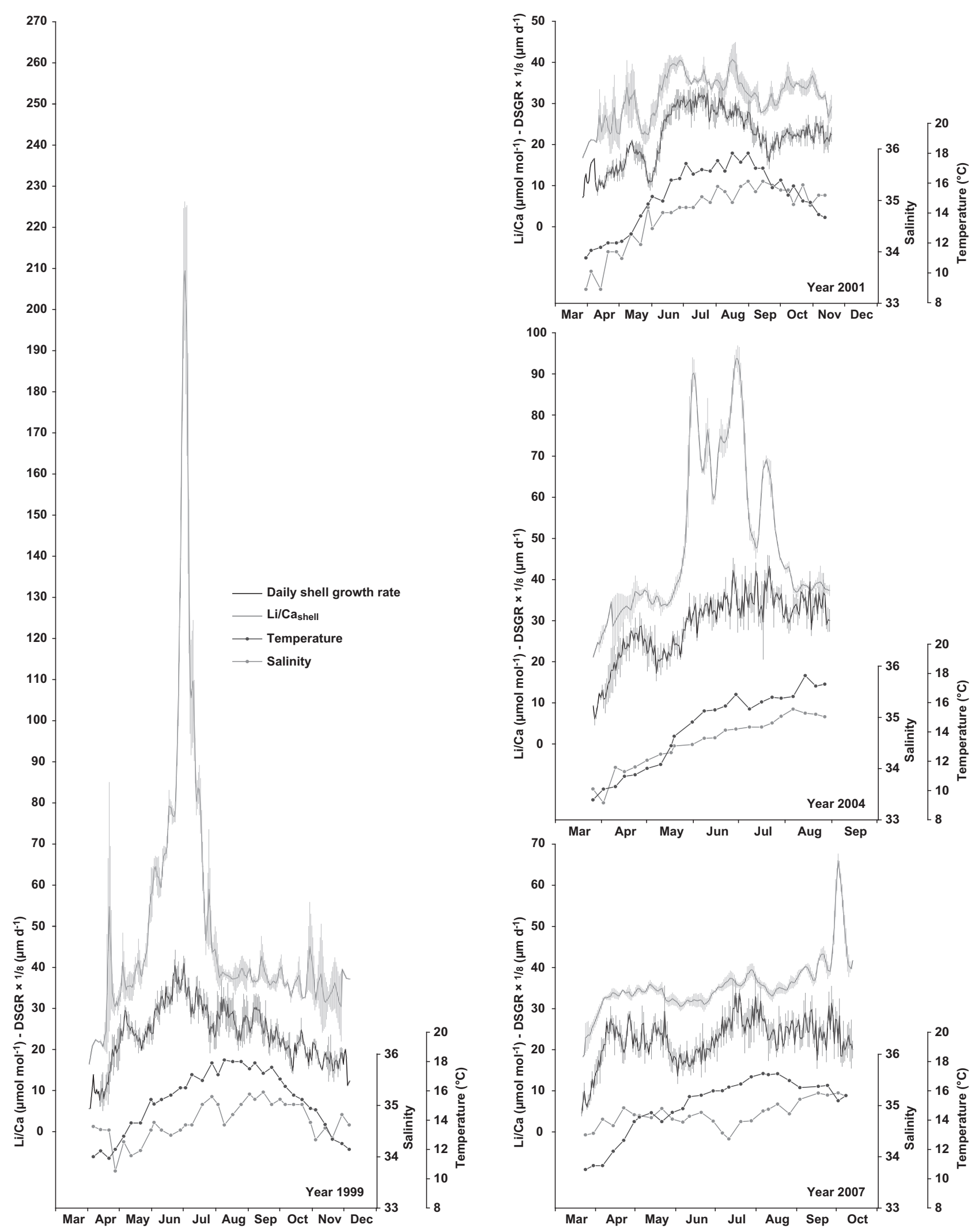

Figure 6: Time series of average $\mathrm{Li} / \mathrm{Ca}_{\text {shell }}$ (grey line; \pm 1 standard error), average daily shell growth rate (DSGR; black line; \pm 1 standard error), seawater temperature (black dotted line) and salinity (grey dotted line) in 1999 ( $n=3$ shells), 2001 ( $n$ $=3), 2004(n=3)$, and $2007(n=4)$, revealing co-variations of shell growth and baseline $\mathrm{Li} / \mathrm{Ca}_{\text {shell }}$. 

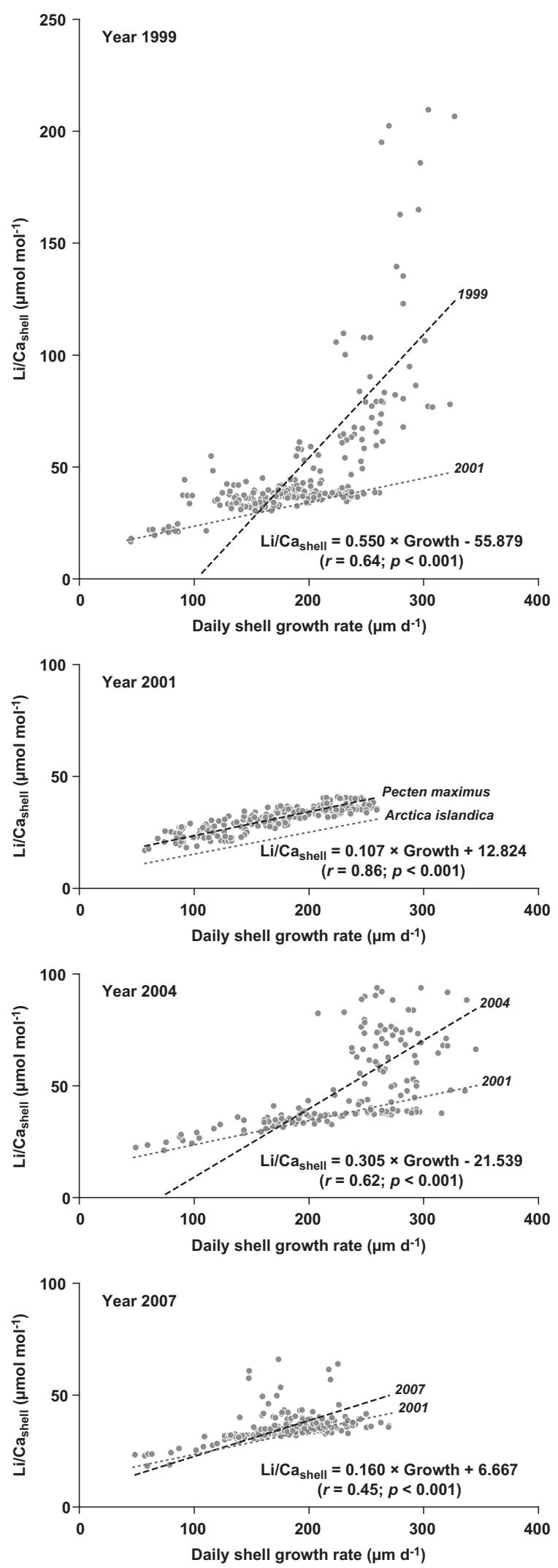

Figure 7: Cross-plots of average $\mathrm{Li} / \mathrm{Ca}$ versus daily shell growth rate for years 1999, 2001, 2004, and 2007. Model II regression lines (SMA; black dashed line) are presented together with regression statistics. For comparative purposes, (i) 2001 SMA regression line is displayed on cross-plots for years 1999, 2004, and 2007 (grey dotted lines), and (ii) Li/Ca versus daily shell growth rate regression line calculated for Arctica islandica (Thébault et al., 2009b) is presented on the 2001 cross-plot (grey dotted line).
Then, we predicted $\mathrm{Li} / \mathrm{Ca}_{\text {shell }}$ variations for each year using average daily shell growth data and Equation 1, assuming that baseline $\mathrm{Li} / \mathrm{Ca}_{\text {shell }}$ variations were only caused by variations in DSGR. Time series of the difference between predicted and observed $\mathrm{Li} / \mathrm{Ca}_{\text {shell }}$, so-called excess $\mathrm{Li} / \mathrm{Ca}_{\text {shell }}\left(\mathrm{Li} / \mathrm{Ca}_{\text {excess }}\right)$, are displayed on Figure 8 , together with DSGR and phytoplankton abundances (except for year 2007 when no phytoplankton data were available). Phytoplankton species were split into two groups: (i) edible diatoms (Chaetoceros spp. and Dactyliosolen fragilissimus), ie. diatoms that have no negative influence on scallop growth in the bay of Brest, and (ii) toxic (Gymnodinium spp., harmful dinoflagellates responsible for red tides; Landsberg, 2002) and aggregate-forming or chain-forming species (Guinardia delicatula and Pseudo-nitzschia spp.) that can hamper scallop growth (Chauvaud et al., 1998; Lorrain et al., 2000; Nézan et al., 2010).

Temporal variations of edible diatom abundance tended to mimic those of $\mathrm{Li} / \mathrm{Ca}_{\text {excess }}$, with a time lag of ca. 3 weeks (Figure 8, upper panels). This was particularly striking in 2004 (proportionality between $\mathrm{Li} / \mathrm{Ca}_{\text {excess }}$ and edible diatom peaks). In 1999, intensity of the edible diatom bloom recorded at SOMLIT-Brest was close to 500 000 cell $\mathrm{L}^{-1}$ on 10 June 1999; this did not seem sufficient to induce the large $\mathrm{Li} / \mathrm{Ca}_{\text {excess }}$ peak recorded in early July 1999. However, this bloom was much larger on Roscanvel Bank than at SOMLIT-Brest, as indicated by the environmental survey performed by Lorrain et al. (2000) in 1999 exactly where our scallops were collected (9 June 1999: 1458000 cell Chaetoceros spp. $\mathrm{L}^{-1}$ ). On the other hand, neither large edible diatom bloom nor $\mathrm{Li} / \mathrm{Ca}_{\text {excess }}$ peak were observed in 2001.

\subsection{Relationship between shell growth retardation and phy- toplankton blooms}

Several growth retardation episodes were recorded on 1999, 2001, and 2004 shells (Figure 8, lower panels). In 1999 and 2001, main accidents always occurred a few days after blooms of Guinardia delicatula (May 1999 and May 2001) and Gymnodinium spp. (September 2001). Some toxic blooms, however, did not seem to hamper shell growth (August 1999 and October 2001). In 2004, a severe growth retardation was observed but was not preceded by a bloom. Finally, a very large bloom of Pseudo-nitzschia spp. occurred on 24 May 2004 (> 800000 cell L ${ }^{-1}$ ), ie. 2 weeks after the growth accident. It should be kept in mind, however, that the timing of blooms may be slightly different at SOMLITBrest and Roscanvel.

\section{Discussion}

Lithium content has rarely been investigated in marine biogenic carbonates in comparison with other elements such as $\mathrm{Mg}$, $\mathrm{Sr}$, or Ba. Most studies on $\mathrm{Li} / \mathrm{Ca}$ ratio in biocarbonates dealt with foraminifera (Delaney et al., 1985; Delaney and Boyle, 1986; Hall and Chan, 2004; Marriott et al., 2004b; Hathorne and James, 2006; Lear and Rosenthal, 2006; Hendry et al., 2009; Lear et al., 2010), and to a lesser extent with corals (Marriott et al., 2004a; Montagna et al., 2006) and brachiopods (Delaney et al., 1989). The 

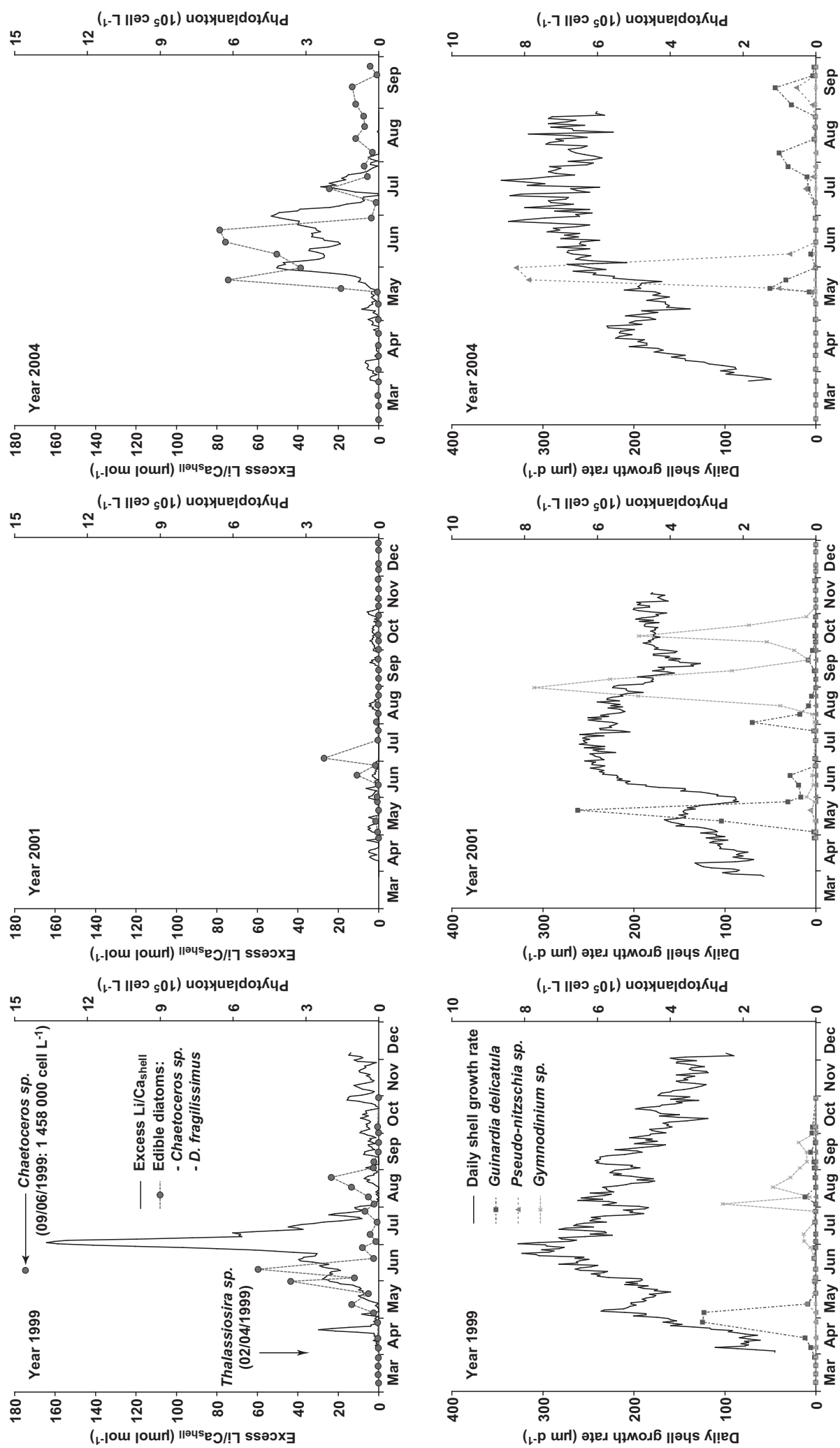

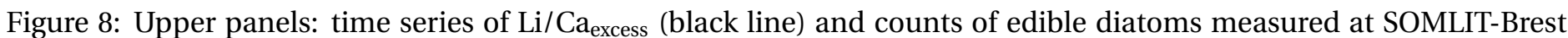
(solid circles; Chaetoceros spp. + Dactyliosolen fragilissimus), for years 1999, 2001, and 2004. Lower panels: time series (1999, 2001, and 2004) of average daily shell growth rate (black line) and abundances of growth-reducing diatoms (solid squares = Guinardia delicatula; solid triangles = Pseudo-nitzschia spp.) and dinoflagellates (light gray crosses = Gymnodinium spp.). 
only known study on $\mathrm{Li} / \mathrm{Ca}$ ratio in bivalve mollusc shells was conducted on juvenile Arctica islandica shells from northeast Iceland (Thébault et al., 2009b). Given the very low inter-individual variability in $\mathrm{Li} / \mathrm{Ca}_{\text {shell }}$ for a given season of growth (Figures 5 and 6), it is likely that this ratio responds either to variations of one (or several) environmental parameter(s), and/or to variations of a physiological process synchronized within a given population. Previous studies put forward several hypotheses to explain variations of $\mathrm{Li} / \mathrm{Ca}$ ratio in calcite: influence of calcification temperature, salinity, dissolved Li concentration in seawater, river inputs of Li-rich silicate particles, calcification rate and seawater carbonate ion $\left(\mathrm{CO}_{3}{ }^{2-}\right)$ concentration. In the following paragraphs, we discuss the merits of these hypotheses to explain temporal variability of $\mathrm{Li} / \mathrm{Ca}_{\text {shell }}$ in Pecten maximus. A new hypothesis, related to phytoplankton blooms, will address the formation of $\mathrm{Li} / \mathrm{Ca}_{\text {shell }}$ peaks.

\subsection{Calcification temperature}

Many authors highlighted inverse relationships between calcification temperature and $\mathrm{Li} / \mathrm{Ca}$ in coralline aragonite (Marriott et al., 2004a; Montagna et al., 2006), in foraminifera (Hall and Chan, 2004; Marriott et al., 2004b), in brachiopods (Delaney et al., 1989), as well as in inorganic calcite (Marriott et al., 2004a). Surprisingly, these results are in contradiction with thermodynamic calculations stating that Li content in calcium carbonate should increase with increasing temperature (Hall and Chan, 2004). Conversely, recent studies on foraminifera and aragonitic bivalve shells found a positive dependance of $\mathrm{Li} / \mathrm{Ca}_{\text {shell }}$ on temperature (Hendry et al., 2009; Thébault et al., 2009b). Simple and multiple linear regressions performed on the whole dataset (1999-2007) indicated that seawater temperature alone explained only $6.2 \%$ of the $\mathrm{Li} / \mathrm{Ca}_{\text {shell }}$ variability $\left(r^{2}=0.062 ; p=0.004 ;\right.$ slope $=2.73$; Table 2$)$. In addition, no thermal anomaly, either positive or negative, was observed synchronously with abrupt $\mathrm{Li} / \mathrm{Ca}_{\text {shell }}$ increases, suggesting that temperature did not induce $\mathrm{Li} / \mathrm{Ca}_{\text {shell }}$ peaks (Figure 6). In 2001 , ie. a year without $\mathrm{Li} / \mathrm{Ca}_{\text {shell }}$ peaks, temperature appeared quite strongly related with $\mathrm{Li} / \mathrm{Ca}_{\text {shell }}\left(r^{2}=0.552 ; p<\right.$ 0.001 ) but thorough observation of Figure 6 indicated that this statistical relationship was not obvious (e.g. in May 2001). It is clear from our results that seawater temperature in the bay of Brest was not the primary factor explaining variations of $\mathrm{Li} / \mathrm{Ca}_{\text {shell }}$ between 1999 and 2007. Therefore, we conclude that calcification temperature has only a weak positive influence on $\mathrm{Li}$ incorporation in Pecten maximus shell calcite precipitated between 8 and $18^{\circ} \mathrm{C}$, thus confirming observations by Thébault et al. (2009b) on juvenile Arctica islandica.

\subsection{Salinity and dissolved lithium concentration}

Salinity was put forward as a possible explanation for variations of $\mathrm{Li} / \mathrm{Ca}$ in inorganic calcite; a salinity decrease, induced by dilution, from 50 to 10 led to a four-fold decrease in $\mathrm{Li} / \mathrm{Ca}_{\text {calcite }}$ (Marriott et al., 2004b). A similar influence of salinity was also highlighted on $\mathrm{Na} / \mathrm{Ca}_{\text {calcite }}$ and might be general for all alkali metals (Ishikawa and Ichikuni, 1984; Marriott et al., 2004b). Indeed, alkali metals are known to be incorporated in an interstitial location in calcite, while they are incorporated in the crystal structure of aragonite in substitution of $\mathrm{Ca}$, leading to formation of $\mathrm{Li}_{2} \mathrm{CO}_{3}$ crystals (Okumura and Kitano, 1986). Consequently, it is their concentration in the calcifying fluid that controls the amount of alkali metals incorporated interstitially within calcite, while there is a competition between alkali metals and Ca to enter aragonite so that it is the $\mathrm{Li} / \mathrm{Ca}$ ratio in the solution which controls $\mathrm{Li} / \mathrm{Ca}_{\text {aragonite. }} \mathrm{Be}$ cause Li concentration is approximatley one order of magnitude lower in rivers than in seawater (rivers: $0.012 \mathrm{ppm}$; seawater: 0.180 ppm; Li, 2000), freshwater inputs leading to salinity decrease therefore also induce a decrease of $\mathrm{Li}$ concentration in seawater. At SOMLIT-Brest monitoring station, salinity variations were very small between 1999 and 2007, ranging between 33 and 35.6 during the season of growth of Pecten maximus (salinity minima below 33 occurred in winter, when scallops did not grow). According to Marriott et al. (2004b), and assuming that biogenic calcite has the same sensitivity to salinity as inorganic calcite, a 1 unit salinity decrease would result in a $3 \%$ decrease in $\mathrm{Li} / \mathrm{Ca}_{\text {shell }}$ for salinity around 35 . Therefore, the salinity range measured at SOMLIT-Brest would be responsible for $8 \%$ changes in $\mathrm{Li} / \mathrm{Ca}_{\text {shell }}$, at most. However, average $\mathrm{Li} / \mathrm{Ca}_{\text {shell }}$ variations ranged from 15 to $40 \mu \mathrm{mol}$ $\mathrm{mol}^{-1}$ in 2001, ie. when $\mathrm{Li} / \mathrm{Ca}_{\text {shell }}$ variations were the weakest. Therefore, salinity, and consequently Li concentration variations in seawater, cannot be responsible alone for $\mathrm{Li} / \mathrm{Ca}_{\text {shell }}$ variations in Pecten maximus. Nevertheless, results of simple and multiple linear regressions, albeit equivocal, suggested that salinity might slightly influence $\mathrm{Li} / \mathrm{Ca}_{\text {shell }}$ variations, in addition to another factor (Table 2).

\subsection{Weathered Li-rich particles}

In their study on $\mathrm{Li} / \mathrm{Ca}_{\text {shell }}$ in juvenile Arctica islandica from northeast Iceland, Thébault et al. (2009b) observed that seasonal variations of the closest river discharge roughly followed the same pattern as $\mathrm{Li} / \mathrm{Ca}_{\text {shell }}$, with maximum values in June. A direct relationship was highlighted by Gislason et al. (2009) between river discharge and mechanical weathering of Icelandic basaltic rocks that have a high Li content. Consequently, Thébault et al. (2009b) hypothesized that high loads of Li-rich suspended basaltic particles probably flow to the sea with Icelandic rivers as soon as snow melts. Direct ingestion of these particles, or their weathering on the seafloor after deposition, may be responsible for significant increases in Li content in shells. Could such an hypothesis explain variations of $\mathrm{Li} / \mathrm{Ca}_{\text {shell }}$ time series in shells of Pecten maximus? No data are available on lithium concentration in shales and sandstones composing Aulne and Elorn rivers catchments. Assuming that these rocks have a high Li content and that they are highly susceptible to mechanical weathering, then high concentrations of Li-rich particles could occurr in the bay of Brest when river flows are at their annual maximum, ie. in January (see figure 4 in Chauvaud et al., 1998). Conversely, Li-rich particles concentration would be lowest during low water periods, ie. from June to October. Given that highest $\mathrm{Li} / \mathrm{Ca}_{\text {shell }}$ values were recorded during these low river levels, it is unlikely that mechanical weathering of river catchments could explain variability of $\mathrm{Li} / \mathrm{Ca}_{\text {shell }}$ in 
Pecten maximus. This possible explanation can therefore likely be ruled out.

\subsection{Calcification rate}

Our results distinctly highlighted a statistically significant positive relationship between $\mathrm{Li} / \mathrm{Ca}_{\text {shell }}$ and DSGR measured along the axis of maximum growth (Figure 7). This was particularly obvious in 2001 when no $\mathrm{Li} / \mathrm{Ca}_{\text {shell }}$ peak occurred (Figures 6 and 7). For years with periods of Li enrichments in shells (1999, 2004, and to a lesser extent 2007), this relationship was still present but partially concealed by the presence of these $\mathrm{Li} / \mathrm{Ca}_{\text {shell }}$ peaks. A similar relationship between $\mathrm{Li} / \mathrm{Ca}_{\text {shell }}$ and shell growth was observed in Arctica islandica (Thébault et al., 2009b). It is worth noting that the slope of the $\mathrm{Li} / \mathrm{Ca}_{\text {shell }}-\mathrm{DSGR}$ relationship is very similar in both study $\left(0.098 \mathrm{~d} \mathrm{~m}^{-1}\right.$ for aragonitic Arctica islandica vs. $0.107 \mathrm{~d} \mathrm{~m}^{-1}$ for calcitic Pecten maximus; Figure 7), suggesting that the control of this physiological factor on $\mathrm{Li}$ incorporation within bivalve mollusc shells may be general and ubiquitous. This control of shell growth is supported by results of the elemental analyses performed on three different growth axes of shell \#6 collected on 5 November 2007. $\mathrm{Li} / \mathrm{Ca}_{\text {shell }}$ ratios displayed very similar temporal variations whatever the growth axis (Figure 4). Nevertheless, average $\mathrm{Li} / \mathrm{Ca}_{\text {shell }}$ ratios were significantly higher on the central axis (ie. axis of maximum growth). These differences could likely be explained by the lower daily shell growth rates on lateral ribs in comparison to the median one.

At this point, a clarification must be made about the difference between daily shell growth rate and absolute calcification rate. DSGR is not equal to absolute calcification rate (or crystal growth rate) because it does not take into account ontogenetic changes in shell thickness and enlargement. A problem is that crystal growth rate is hardly measurable. Lorrain et al. (2004) tried to estimate it more precisely during the second year of growth of Pecten maximus shells from the Bay of Brest by measuring their daily carbon precipitation rate (DCPR). It appeared than DSGR and DCPR slightly differed. Therefore, it must be kept in mind that DSGR is only an approximation of absolute calcification rate.

Beside bivalves, several studies also suggested that changes in calcification rate, that could in turn reflect longterm changes in $\mathrm{CO}_{3}{ }^{2-}$ concentration and carbonate saturation state, may be responsible for variations of $\mathrm{Li} / \mathrm{Ca}$ in foraminiferal calcite (Hall and Chan, 2004; Lear and Rosenthal, 2006; Hendry et al., 2009). The mechanisms involved in these physiological effects have barely been studied. The influence of calcification rate on Li incorporation in biocarbonates might be related to the presence of calcification anomalies. Indeed, Busenberg and Plummer (1985) suggested that the amount of $\mathrm{Na}$ incorporated in calcite may be highly dependent on the number of crystal defects, which is in turn favoured by faster growth rates. By analogy, and because $\mathrm{Na}$ and $\mathrm{Li}$ are both situated in interstitial positions in the calcite crystals (Okumura and Kitano, 1986), it is reasonable to hypothesize that the same effect controls $\mathrm{Li} / \mathrm{Ca}_{\text {shell }}$. The faster a shell grows, the more defaults there are in the crystal structure, and the more interstitial spaces are available for $\mathrm{Li}$ inclusions. Concurrent measurements of $\mathrm{Li} / \mathrm{Ca}_{\text {shell }}$ and scanning electron microscope observations of crystal fabrics in the same shell might help confirming this hypothesis. In any case, our results suggested that $\mathrm{Li} / \mathrm{Ca}_{\text {shell }}$ was probably controlled by calcification rate (as estimated by DSGR) most of the year (ie. outside peak periods)

\subsection{Phytoplankton blooms}

Once the influence of shell growth on $\mathrm{Li} / \mathrm{Ca}_{\text {shell }}$ has been removed, $\mathrm{Li} / \mathrm{Ca}_{\text {excess }}$ showed very distinct peaks which may be explained by phytoplankton dynamics (Figure 8). Indeed, a striking similarity and proportionality was highlighted between $\mathrm{Li} / \mathrm{Ca}_{\text {excess }}$ and abundance of Chaetoceros spp. and Dactyliosolen fragilissimus, ie. diatoms that are known to be eaten by scallops in the bay of Brest with no detrimental influence on physiology. An exception is Chaetoceros sociale that can form large aggregates and alter scallop growth (Chauvaud et al., 1998) but this species was not observed between 1999 and 2004 (except one occurrence on 23 September 2003 with 8720 cell L$^{-1}$ ). Important shell growth retardation occurred only a few days after every large bloom of the diatom Guinardia delicatula. This confirms observations of Chauvaud et al. (1998) and Lorrain et al. (2000) who suggested that sedimentation of large aggregates of this species affected food intake and/or respiratory activity of the scallops by gill clogging or oxygen depletion, thus strongly hampering shell growth. Therefore, although this species does not produce toxins, it can definitely not be classified as an edible diatom.

Many species of the diatom genus Pseudo-nitzschia are known to produce a powerful neurotoxin named domoic acid (DA), that can generate serious trouble and amnesia (Amnesic Shellfish Poisoning ASP) in human populations feeding on marine resources (Bates et al., 1989). Lithium is known to be an element significantly stimulating production of DA by Pseudo-nitzschia spp. (Subba Rao et al., 1998). As DA is a powerful chelating agent, synthesis and release of large quantities of this neurotoxin might be an attempt to sequester lithium (Stewart and Subba Rao, 1995). Given that many marine bivalve species, especially Pecten maximus, are known for their capability of accumulating high DA levels (James et al., 2005), it could be hypothesized that peaks of $\mathrm{Li} / \mathrm{Ca}_{\text {excess }}$ were produced (i) after direct ingestion of DA-enriched Pseudo-nitzschia, and/or (ii) after ingestion of dissolved DA released in seawater following blooms of toxin-producing Pseudo-nitzschia. Only two large blooms of Pseudo-nitzschia were recorded at SOMLIT-Brest between 1999 and 2004 (July 2000 and May 2004). Therefore, most of the $\mathrm{Li} / \mathrm{Ca}_{\text {excess }}$ peaks cannot be attributed to such blooms. An exception may be the $\mathrm{Li} / \mathrm{Ca}_{\text {excess }}$ peak recorded in early June 2004, ie. a few weeks after high Pseudo-nitzschia concentrations at SOMLIT-Brest. However, there are some uncertainties about the exact timing of this bloom at Roscanvel. Indeed, a shell growth retardation was recorded in early May 2004. Concentrations of Guinardia delicatula and Gymnodinium spp. were definitely too low to explain this growth reduction. We suppose that the latter was induced by Pseudo-nitzschia and that the bloom recorded in late May at SOMLIT-Brest actually occurred 2-3 weeks earlier at Roscanvel. Indeed, blooms of 
Pseudo-nitzschia are known to display an especially high spatial variability and they can occur at a very local scale even in a small-size ecosystem such as the bay of Brest (H. Hégaret, pers. comm.). Rines et al. (2002) also highlighted the possibility of Pseudo-nitzschia populations to be concentrated into thin horizontal layers, from centimetres to a few metres within the water column or near to the bottom due to the physical transport of water masses. Moreover, most members of the Pseudo-nitzschia genus are elongated diatoms that are known for their ability to form chains (Hasle, 1994), thus possibly hampering shell growth by gill clogging. And, finally, Liu et al. (2008) found negative impacts on growth rate and survival of juvenile Pecten maximus when exposed to food previously enriched with DA.

Consequently, we suggest (i) that shell growth retardations were induced by blooms of either chain-forming diatoms (Pseudo-nitzschia spp.), aggregate-forming diatoms (Guinardia delicatula), and/or toxic phytoplankton species (Pseudo-nitzschia spp. and dinoflagellate Gymnodinium spp.), and (ii) that occurrence and amplitude of $\mathrm{Li} / \mathrm{Ca}_{\text {excess }}$ peaks were probably related to timing and magnitude of edible diatom blooms (especially Chaetoceros spp. and Dactyliosolen fragilissimus). Nevertheless, a question remains: what is the exact relationship between edible diatoms and $\mathrm{Li}$ in shells?

It has previously been estimated that biogenic carbonate and biogenic opal production were two of the main removal processes of lithium from the ocean (Coplen et al., 2002). However, while marine carbonates contain $2 \mathrm{ppm}$ of lithium on average, Quaternary radiolarian and diatomaceous oozes are one order of magnitude more enriched in lithium (about 30 ppm; Coplen et al., 2002). Biogenic opal originating from diatom frustules was assumed to be a major source of $\mathrm{Li}$ in diatomaceous sediments of the Gulf of California, based on a Li concentration maximum in pore fluids within a zone of active silica diagenesis (Gieskes et al., 1982). It could therefore be assumed that dissolution of Chaetoceros spp. and Dactyliosolen fragilissimus frustules in the stomach of Pecten maximus led to an increase in lithium concentration in the internal fluids and, ultimately, in the shell. Unfortunately, no data are available about dissolution rates of diatom frustules in digestive tract of molluscs. Nevertheless, the residence time of biogenic silica in sediments of the bay of Brest has previously been estimated to be on the order of 1 month (Chauvaud et al., 2000). Similarly, Laruelle et al. (2009) found that the benthic recycling flux of dissolved silicon to the water column of the bay of Brest follows the diatom deposition pulse with a time lag of 1 to 2 months. These data are consistent with laboratory experiments indicating that opal dissolution is quite slow (2.9-6.6 \% $\mathrm{d}^{-1}$, ie. frustules are entirely dissolved after 15-34 days; Moriceau et al., 2007). Assuming that these rates are of the same order of magnitude in scallop stomach, then these data give strength to our hypothesis as it provides an explanation for the ca. 3 week time lag between edible diatom blooms and $\mathrm{Li} / \mathrm{Ca}_{\text {excess }}$ peaks.

\section{Summary and conclusions}

This first study on $\mathrm{Li} / \mathrm{Ca}_{\text {shell }}$ ratio in calcitic bivalves provided promising and definitely very interesting information. First of all, individuals from a given population presented very similar time series of $\mathrm{Li} / \mathrm{Ca}_{\text {shell }}$, which suggests that incorporation of this element responds to variations of environmental parameters affecting simultaneously all specimens in a given area. Secondly, a strong and significant linear relationship has been found between daily shell growth rate and variations of $\mathrm{Li} / \mathrm{Ca}_{\text {shell }}$ outside $\mathrm{Li}$ enrichment periods, thus confirming previous results obtained on shells of Arctica islandica (Thébault et al., 2009b). Interestingly, the slopes of these shell growth-Li/Ca $\mathrm{Ca}_{\text {shell }} \mathrm{re}$ lationships are very similar for both species (about $0.1 \mathrm{~d}$ $\mathrm{m}^{-1}$ ). Thirdly, seawater temperature had only a weak positive influence on Li incorporation in Pecten maximus shell calcite growing over the range $8-18^{\circ} \mathrm{C}$. And finally, we provided prima-facie evidence towards an influence of diatom blooms on $\mathrm{Li} / \mathrm{Ca}_{\text {shell }}$ enrichments.

To conclude, we suggest that $\mathrm{Li} / \mathrm{Ca}_{\text {shell }}$ ratio may be used as a proxy for timing and magnitude of diatom blooms in coastal ecosystems. Hence, this proxy would be very useful to assess (i) importance of past phytoplankton blooms as diatoms were dominant in pre-industrial "pristine" coastal ecosystems due to higher $\mathrm{Si} / \mathrm{N}$ ratios than today (Smayda, 1990), and (ii) magnitude of recent shifts from diatoms to non-siliceous phytoplankton in areas affected by anthropogenic activities (e.g., N-enriched freshwater inputs). A limit of this proxy would be that variations of abundance of non-edible diatoms could likely not be reconstructed using this proxy. However, these species represent only a small fraction of coastal diatom communities. Undoubtedly, Li should therefore be added in the list of elements commonly analysed by ICP-MS in the framework of sclerochemical studies.

\section{Acknowledgments}

We kindly acknowledge Manuel Richard and Claire Bassoullet (Laboratoire Domaines Océaniques, Université de Bretagne Occidentale, France) for elemental analyses of Pecten maximus shells, Beatriz Beker (Centre d'Océanologie de Marseille / Institut Universitaire Européen de la Mer, France) for counting and identification of phytoplankton species, and Hélène Hégaret (Laboratoire des sciences de l'environnement marin, CNRS, France) for helpful comments on toxic phytoplankton dynamics. Thanks are due to the SOMLIT-Brest (Service d'Observation en Milieu LITtoral, INSU-CNRS) group responsible for water sampling, analysis and data management. This manuscript has greatly benefited from critical reviews and very helpful comments by David P. Gillikin (guest editor), Leon Clarke, and an anonymous reviewer. This work was supported by the Region Bretagne and the French program ANR-Blanc (Agence Nationale de la Recherche - CHIVAS project). 


\section{References}

Barats, A., Amouroux, D., Chauvaud, L., Pécheyran, C., Lorrain, A., Thébault, J., Church, T. M., Donard, O. F. X., 2009. High frequency barium profiles in shells of the Great Scallop Pecten maximus: a methodical long-term and multi-site survey in Western Europe. Biogeosciences 6, 157-170.

Barats, A., Amouroux, D., Pécheyran, C., Chauvaud, L., Thébault, J., Donard, O. F. X., 2010. Spring molybdenum enrichment in scallop shells: a potential tracer of diatom productivity in temperate coastal environments (Brittany, NW France). Biogeosciences 7, 233-245.

Barrat, J.-A., Keller, F., Amossé, J., Taylor, R., Nesbitt, R., Hirata, T., 1996. Determination of rare earth elements in sixteen silicate reference samples by ICP-MS after Tm addition and ion exchange separation. Geostandards Newsletter 20, 133-139.

Bates, S., Bird, C., de Freitas, A., Foxall, R., Gilgan, M., Hanic, L. A., Johnson, G. R., McCulloch, A. W., Odense, P., Pocklington, R., Quilliam, M. A., Sim, P. G., Smith, J. C., Subba Rao, D., Todd, E. C. D., Walter, J. A., Wright, J. L. C., 1989. Pennate diatom Nitzschia pungens as the primary source of domoic acid, a toxin in shellfish from eastern Prince Edward Island, Canada. Canadian Journal of Fisheries and Aquatic Sciences 46, 1203-1215.

Bayon, G., Barrat, J.-A., Etoubleau, J., Benoit, M., Bollinger, C., Révillon, S., 2009. Determination of rare earth elements, Sc, Y, Zr, Ba, Hf and Th in geological samples by ICP-MS after Tm addition and alkaline fusion. Geostandards and Geoanalytical Research 33, 51-62.

Busenberg, E., Plummer, L. N., 1985. Kinetic and thermodynamic factors controlling the distribution of $\mathrm{SO}_{3}^{2-}$ and $\mathrm{Na}^{+}$in calcites and selected aragonites. Geochimica et Cosmochimica Acta 49, 713-725.

Carré, M., Bentaleb, I., Fontugne, M., Lavallée, D., 2005. Strong El Niño events during the early Holocene: stable isotope evidence from Peruvian sea-shells. The Holocene 15, 42-47.

Chauvaud, L., Jean, F., Ragueneau, O., Thouzeau, G., 2000. Long-term variation of the Bay of Brest ecosystem: benthic-pelagic coupling revisited. Marine Ecology Progress Series 200, 35-48.

Chauvaud, L., Lorrain, A., Dunbar, R. B., Paulet, Y.-M., Thouzeau, G., Jean, F., Guarini, J.-M., Mucciarone, D., 2005. Shell of the Great Scallop Pecten maximus as a high-frequency archive of paleoenvironmental changes. Geochemistry Geophysics Geosystems 6, Q08001, doi:10.1029/2004GC000890.

Chauvaud, L., Thouzeau, G., Paulet, Y.-M., 1998. Effects of environmental factors on the daily growth rate of Pecten maximus juveniles in the Bay of Brest (France). Journal of Experimental Marine Biology and Ecology 227, 83-111.

Chauvaud, L., Thébault, J., Clavier, J., Lorrain, A., Strand, O., 2011. What's hiding behind ontogenetic $\delta^{13} \mathrm{C}$ variations in mollusk shells? New insights from the great scallop (Pecten maximus). Estuaries and Coasts 34, 211-220.

Chen, C.-T., Liu, K.-K., MacDonald, R., 2003. Continental margin exchanges. In: Fasham, M. (Ed.), Ocean biogeochemistry: the role of the ocean carbon cycle in global change. Springer, pp. 53-97.

Cloern, J. E., 2001. Our evolving conceptual model of the coastal eutrophication problem. Marine Ecology Progress Series 210, 223-253.

Coplen, T., Böhlke, J., De Bièvre, P., Ding, T., Holden, N., Hopple, J., Krouse, H., Lamberty, A., Peiser, H., Révész, K., Rieder, S., Rosman, K., Roth, E., Taylor, P., Vocke Jr., R., Xiao, Y., 2002. Isotope-abundance variations of selected elements (IUPAC technical report). Pure and Applied Chemistry 74, 1987-2017.

Delaney, M. L., Boyle, E. A., 1986. Lithium in foraminiferal shells: implications for high-temperature hydrothermal circulation fluxes and oceanic crustal generation rates. Earth and Planetary Science Letters 80, 91-105.

Delaney, M. L., Bé, A. W., Boyle, E. A., 1985. Li, Sr, Mg, and Na in foraminiferal calcite shells from laboratory culture, sediment traps, and sediment cores. Geochimica et Cosmochimica Acta 49, 1327-1341.

Delaney, M. L., Popp, B. N., Lepzelter, C. G., Anderson, T. F., 1989. Lithium-to-calcium ratios in modern, Cenozoic, and Paleozoic articulate brachiopod shells. Paleoceanography 4, 681-691.

Field, C. B., Behrenfeld, M. J., Randerson, J. T., Falkowski, P. G., 1998. Primary production of the biosphere: Integrating terrestrial and oceanic components. Science $281,237-240$.

Gieskes, J., Elderfield, H., Lawrence, J., Johnson, J., Meyers, B., Campbell, A., 1982 Geochemistry of interstitial waters and sediments, Leg 64, Gulf of California. Initial Reports of the Deep Sea Drilling Project 64, 675-694.

Gillikin, D. P., Dehairs, F., Baeyens, W., Navez, J., Lorrain, A., André, L., 2005. Inter- and intra-annual variations of $\mathrm{Pb} / \mathrm{Ca}$ ratios in clam shells (Mercenaria mercenaria): A record of anthropogenic lead pollution? Marine Pollution Bulletin 50, 1530-1540.
Gillikin, D. P., Dehairs, F, Lorrain, A., Steenmans, D., Baeyens, W., André, L., 2006. Barium uptake into the shells of the common mussel (Mytilus edulis) and the poten tial for estuarine paleo-chemistry reconstruction. Geochimica et Cosmochimica Acta 70, 395-407.

Gillikin, D. P., Lorrain, A., Paulet, Y.-M., André, L., Dehairs, F., 2008. Synchronous barium peaks in high-resolution profiles of calcite and aragonite marine bivalve shells. Geo-Marine Letters 28, 351-358.

Gislason, S. R., Oelkers, E. H., Eiriksdottir, E. S., Kardjilov, M. I., Gisladottir, G., Sig fusson, B., Snorrason, A, Elefsen, S, Hardardottir, J., Torssander, P, Oskarsson, N., 2009. Direct evidence of the feedback between climate and weathering. Earth and Planetary Science Letters 277, 213-222.

Hall, J. M., Chan, L. H., 2004. Li/Ca in multiple species of benthic and planktonic foraminifera: thermocline, latitudinal, and glacial-interglacial variation. Geochimica et Cosmochimica Acta 68, 529-545.

Hasle, G., 1994. Pseudo-nitzschia as a genus distinct from Nitzschia (Bacillariophyceae). Journal of Phycology 30, 1036-1039.

Hathorne, E. C., James, R. H., 2006. Temporal record of lithium in seawater: A tracer for silicate weathering? Earth and Planetary Science Letters 246, 393-406.

Hendry, K., Rickaby, R., Meredith, M., Elderfield, H., 2009. Controls on stable isotope and trace metal uptake in Neogloboquadrina pachyderma (sinistral) from an Antarctic sea-ice environment. Earth and Planetary Science Letters 278, 67-77.

Hickson, J. A., Johnson, A. L. A., Heaton, T. H. E., Balson, P. S., 1999. The shell of the Queen Scallop Aequipecten opercularis (L.) as a promising tool for palaeoenvironmental reconstruction: evidence and reasons for equilibrium stable-isotope incorporation. Palaeogeography, Palaeoclimatology, Palaeoecology 154, 325-337.

Ishikawa, M., Ichikuni, M., 1984. Uptake of sodium and potassium by calcite. Chemical geology 42, 137-146.

Jackson, J. B. C., 2001. What was natural in the coastal ocean? Proceedings of the National Academy of Sciences 98, 5411-5418.

James, K. J., Gillman, M., Amandi, M. F., López Rivera, A., Puente, P. F., Lehane, M. Mitrovic, S., Furey, A., 2005. Amnesic shellfish poisoning toxins in bivalve molluscs in Ireland. Toxicon 46, 852-858.

Landsberg, J. H., 2002. The effects of harmful algal blooms on aquatic organisms. Reviews in Fisheries Science 10, 113-390.

Laruelle, G., Regnier, P., Ragueneau, O., Kempa, M., Moriceau, B., Ni Longphuirt, S. Leynaert, A., Thouzeau, G., Chauvaud, L., 2009. Benthic-pelagic coupling and the seasonal silica cycle in the Bay of Brest (France): new insights from a coupled physical-biological model. Marine Ecology Progress Series 385, 15-32.

Larvor, H., Cuif, J., Devauchelle, N., 1996. Abnormal melanization and microstructural distortions of the shell of great scallop living in shallow water. Aquaculture International 4, 237-252.

Lazareth, C. E., Vander Putten, E., Andre, L., Dehairs, F., 2003. High-resolution trace element profiles in shells of the mangrove bivalve Isognomon ephippium: a record of environmental spatio-temporal variations? Estuarine, Coastal and Shelf Science 57, 1103-1114.

Lear, C., Mawbey, E., Rosenthal, Y., 2010. Cenozoic benthic foraminiferal Mg/Ca and $\mathrm{Li} / \mathrm{Ca}$ records: Toward unlocking temperatures and saturation states. Paleoceanography 25, PA4215, 10.1029/2009PA001880.

Lear, C. H., Rosenthal, Y., 2006. Benthic foraminiferal Li/Ca: Insights into Cenozoic seawater carbonate saturation state. Geology 34, 985-988.

Li, Y.-H., 2000. A compendium of geochemistry: From solar nebula to the human brain. Princeton University Press.

Liu, H., Kelly, M., Campbell, D., Fang, J., Zhu, J., 2008. Accumulation of domoic acid and its effect on juvenile king scallop Pecten maximus (Linnaeus, 1758). Aquaculture 284, 224-230.

Lorrain, A., 2002. Utilisation de la coquille Saint-Jacques comme traceur environnemental : approches biologique et biogéochimique. $\mathrm{PhD}$ thesis, Université de Bretagne Occidentale, Brest, France.

Lorrain, A., Paulet, Y., Chauvaud, L., Savoye, N., Nezan, E., Guérin, L., 2000. Growth anomalies in Pecten maximus from coastal waters (Bay of Brest, France): relationship with diatom blooms. Journal of the Marine Biological Association of the United Kingdom 80, 667-673.

Lorrain, A., Paulet, Y.-M., Chauvaud, L., Dunbar, R. B., Mucciarone, D., Fontugne, M. 2004. $\delta^{13} \mathrm{C}$ variation in scallop shells: Increasing metabolic carbon contribution with body size? Geochimica et Cosmochimica Acta 68, 3509-3519.

Marriott, C. S., Henderson, G. M., Belshaw, N. S., Tudhope, A. W., 2004a. Temperature dependence of $\delta^{7} \mathrm{Li}, \delta^{44} \mathrm{Ca}$ and $\mathrm{Li} / \mathrm{Ca}$ during growth of calcium carbonate. Earth and Planetary Science Letters 222, 615-624.

Marriott, C. S., Henderson, G. M., Crompton, R., Staubwasser, M., Shaw, S., 2004b. Effect of mineralogy, salinity, and temperature on $\mathrm{Li} / \mathrm{Ca}$ and $\mathrm{Li}$ isotope composition of calcium carbonate. Chemical Geology 212, 5-15. 
McConnaughey, T., Gillikin, D., 2008. Carbon isotopes in mollusk shell carbonates. Geo-Marine Letters 28, 287-299.

Miller, A. J., Gabric, A. J., Moisan, J. R., Chai, F., Neilson, D. J., Pierce, D. W., Di Lorenzo, E., 2006. Global change and oceanic primary productivity: Effects of oceanatmosphere-biological feedbacks. In: Kawahata, H., Awaya, Y. (Eds.), Global climate change and response of the carbon cycle in the Equatorial Pacific and Indian Oceans and adjacent landmasses. Elsevier, pp. 29-65.

Montagna, P., McCulloch, M., Mazzoli, C., Silenzi, S., Schiaparelli, S., 2006. Li/Ca ratios in the Mediterranean non-tropical coral Cladocora caespitosa as a potential paleothermometer. Geophysical Research Abstracts 8, abstract 03695.

Moriceau, B., Garvey, M., Ragueneau, O., Passow, U., 2007. Evidence for reduced biogenic silica dissolution rates in diatom aggregates. Marine Ecology Progress Series $333,129-142$.

Nézan, E., Chomérat, N., Bilien, G., Boulben, S., Duval, A., Ryckaert, M., 2010. Pseudonitzschia australis on French Atlantic coast-an unusual toxic bloom. Harmful Algae News $41,1-2$.

Okumura, M., Kitano, Y., 1986. Coprecipitation of alkali metal ions with calcium carbonate. Geochimica et Cosmochimica Acta 50, 49-58.

Rines, J., Donaghay, P., Dekshenieks, M., Sullivan, J., Twardowski, M., 2002. Thin layers and camouflage: hidden Pseudo-nitzschia spp.(Bacillariophyceae) populations in a fjord in the San Juan Islands, Washington, USA. Marine Ecology Progress Series 225, 123-137.

Sarmiento, J. L., Slater, R., Barber, R., Bopp, L., Doney, S. C., Hirst, A. C., Kleypas, J., Matear, R., Mikolajewicz, U., Monfray, P., Soldatov, V., Spall, S. A., Stouffer, R. 2004. Response of ocean ecosystems to climate warming. Global Biogeochemical Cycles 18, GB3003, doi:10.1029/2003GB002134.

Schöne, B., Zhang, Z., Radermacher, P., Thébault, J., Jacob, D., Nunn, E., Maurer, A.-E. 2011. Sr/Ca and Mg/Ca ratios of ontogenetically old, long-lived bivalve shells (Arctica islandica) and their function as paleotemperature proxies. Palaeogeography, Palaeoclimatology, Palaeoecology 302, 52-64.

Schöne, B. R., Oschmann, W., Rössler, J., Castro, A. D. F, Houk, S. D., Kröncke, I. Dreyer, W., Janssen, R., Rumohr, H., Dunca, E., 2003. North Atlantic Oscillation dynamics recorded in shells of a long-lived bivalve mollusk. Geology 31, 10371040.

Smayda, T., 1990. Novel and nuisance phytoplankton blooms in the sea: Evidence for a global epidemic. In: Graneli, E. (Ed.), Toxic marine phytoplankton. Elsevier, pp. $29-40$.
Stecher, H., Krantz, D., Lord III, C., Luther III, G., Bock, K., 1996. Profiles of strontium and barium in Mercenaria mercenaria and Spisula solidissima shells. Geochimica et Cosmochimica Acta 60, 3445-3456.

Stewart, J. E., Subba Rao, D. V., 1995. Phycotoxins: Physiology and production. Science Review of the Bedford Institute of Oceanography 1994-1995, 45-51.

Sturgeon, R., Willie, S., Yang, L., Greenberg, R., Spatz, R., Chen, Z., Scriver, C., Clancy, V., Lam, J., Thorrold, S., 2005. Certification of a fish otolith reference material in support of quality assurance for trace element analysis. Journal of Analytical Atomic Spectrometry 20, 1067-1071.

Subba Rao, D., Pan, Y., Mukhida, K., 1998. Production of domoic acid by Pseudonitzschia multiseries Hasle, affected by lithium. Marine Ecology 19, 31-36.

Thébault, J., Chauvaud, L., L'Helguen, S., Clavier, J., Barats, A., Jacquet, S., Pécheyran, C., Amouroux, D., 2009a. Barium and molybdenum records in bivalve shells: geochemical proxies for phytoplankton dynamics in coastal environments? Limnology and Oceanography 54, 1002-1014.

Thébault, J., Schöne, B. R., Hallmann, N., Barth, M., Nunn, E. V., 2009b. Investigation of $\mathrm{Li} / \mathrm{Ca}$ variations in aragonitic shells of the ocean quahog Arctica is landica, northeast Iceland. Geochemistry Geophysics Geosystems 10, Q12008, doi:10.1029/2009GC002789

Twilley, R., Chen, R., Hargis, T., 1992. Carbon sinks in mangroves and their implications to carbon budget of tropical coastal ecosystems. Water, Air, and Soil Pollution 64, 265-288.

Vander Putten, E., Dehairs, F., Keppens, E., Baeyens, W., 2000. High resolution distribution of trace elements in the calcite shell layer of modern Mytilus edulis: en vironmental and biological controls. Geochimica et Cosmochimica Acta 64, 9971011.

Wanamaker Jr., A. D., Kreutz, K. J., Schöne, B. R., Pettigrew, N., Borns, H. W., Introne, D. S., Belknap, D., Maasch, K. A., Feindel, S., 2008. Coupled North Atlantic slope water forcing on Gulf of Maine temperatures over the past millennium. Climate Dynamics 31, 183-194.

Yentsch, C. S., Menzel, D. W., 1963. A method for the determination of phytoplankton chlorophyll and phaeophytin by fluorescence. Deep Sea Research and Oceanographic Abstracts 10, 221-231. 